\title{
Review Article \\ Volcanic Ash versus Mineral Dust: Atmospheric Processing and Environmental and Climate Impacts
}

\author{
Baerbel Langmann \\ Institute of Geophysics, University of Hamburg, Geomatikum, Office 1411, Bundesstraße 55, 20146 Hamburg, Germany \\ Correspondence should be addressed to Baerbel Langmann; baerbel.langmann@zmaw.de
}

Received 29 April 2013; Accepted 26 May 2013

Academic Editors: A. M. Siani and E. Tagaris

Copyright (c) 2013 Baerbel Langmann. This is an open access article distributed under the Creative Commons Attribution License, which permits unrestricted use, distribution, and reproduction in any medium, provided the original work is properly cited.

\begin{abstract}
This review paper contrasts volcanic ash and mineral dust regarding their chemical and physical properties, sources, atmospheric load, deposition processes, atmospheric processing, and environmental and climate effects. Although there are substantial differences in the history of mineral dust and volcanic ash particles before they are released into the atmosphere, a number of similarities exist in atmospheric processing at ambient temperatures and environmental and climate impacts. By providing an overview on the differences and similarities between volcanic ash and mineral dust processes and effects, this review paper aims to appeal for future joint research strategies to extend our current knowledge through close cooperation between mineral dust and volcanic ash researchers.
\end{abstract}

\section{Introduction}

Volcanic ash represents a major product of volcanic eruptions [1-3]. It is formed by fragmentation processes of the magma and the surrounding rock material of volcanic vents $[1,4]$. Depending on the strength of a volcanic eruption, volcanic ash is released into the free troposphere or even the stratosphere $[1,5]$, where it is transported by the prevailing winds until it is removed from the atmosphere by gravitational settling and wet deposition [6]. Volcanic ash is also known to be mobilised by wind from its deposits [712], which have accumulated after volcanic eruptions on land located along the main transport directions of the volcanic cloud, which spreads out over hundreds to thousands of kilometres, dependent on wind speed, ash size, ash density, and eruption magnitude. In contrast to atmospheric mineral dust, the importance of volcanic ash for climate has long been considered negligible [5].

The global mineral dust cycle and its interactions with the Earth's climate system have been studied widely [1318]. Mineral dust aerosols affect the radiative forcing of the atmosphere directly $[13,19]$ and indirectly by acting as cloud condensation or ice nuclei $[20,21]$. Furthermore, mineral dust aerosols influence ozone photochemistry [22, 23] and supply nutrients to marine [24] and terrestrial ecosystems
[25]. Vice versa, climate variability affects the mineral dust burden of the atmosphere through modifications of precipitation, vegetation cover, and wind [15].

This review contrasts the environmental and climatic effects of volcanic ash versus those of mineral dust. A stronger focus is put on the description of volcanic ash, whereas mineral dust effects are described in less detail, but with referencing the extensive literature. Similarities and differences will be emphasised (Figure 1) to facilitate the different scientific communities studying volcanic ash and mineral dust to learn from each other in an interdisciplinary way, to think about future joint research projects, and to address the important, challenging, and compelling questions, which are still open such as the following:

(i) which physical-chemical processes during long-range transport in the atmosphere affect the surface chemical composition of volcanic ash and mineral dust?

(ii) how important is resuspension of volcanic ash from deposits on land for posteruptive climate and environmental effects?

(iii) what are the reasons for the huge variability of nutrient and toxic element fluxes from volcanic ashes and mineral dust to the surface ocean? 


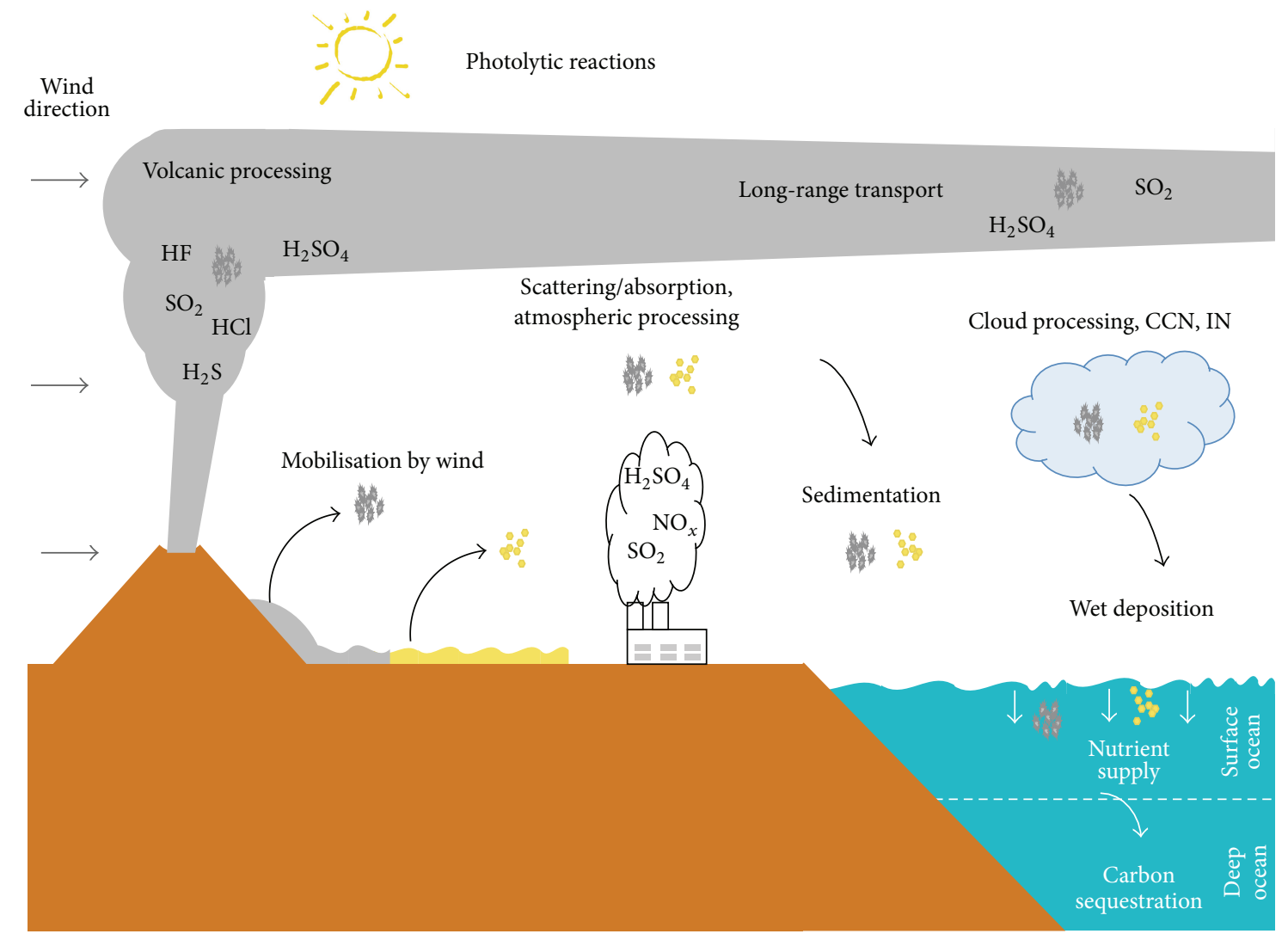

FIGURE 1: Schematic diagram showing the important processes controlling environmental and climate effects of volcanic ash (in grey) and mineral dust (in yellow). (CCN: cloud condensation nuclei; IN: ice nuclei).

(iv) how important is volcanic iron fertilisation of the surface ocean and the associated modifications of atmospheric $\mathrm{CO}_{2}$ in comparison to that induced by mineral dust?

(v) how relevant is the role of volcanic ash and/or mineral dust for the Earth's climate?

Section 2 gives definitions for mineral dust and volcanic ash and provides information of the general chemical and physical properties. Sources, atmospheric load, and deposition processes are discussed in Section 3, atmospheric processing in Section 4, and environmental and climatic impacts in Section 5. The last section summarises needs for future research.

\section{Definitions and Chemical and Physical Properties}

2.1. General Definition. According to the "Glossary of Atmospheric Chemistry Terms" [26], dust consists of small, dry, and solid particles released into the atmosphere by natural forces, such as wind, volcanic eruptions, and by mechanical or man-made activities (e.g., crushing, milling, and shoveling). Dust particles are usually in the size range from about 1 to $100 \mu \mathrm{m}$ in diameter and settle slowly from the atmosphere due to gravity [26]. Thus, mineral dust and volcanic ash may constitute a fraction of all recorded dust.
To distinguish between mineral dust and volcanic ash the following definitions are used: atmospheric mineral dust originates from a suspension of minerals constituting the soil, whereas volcanic ash is loose and unconsolidated material with particle diameters less than $2 \mathrm{~mm}$ [27] being either dispersed in the atmosphere or being deposited above the soil. Weathered mineral dust may originate from volcanic tephra (tephra is defined as any fragmental material produced by a volcanic eruption regardless of composition and fragment size; [28]); however, volcanic ash represents relatively fresh material produced during a recent volcanic eruption (recent in this context means no longer than about 100 years ago) and is therefore different form mineral dust.

2.2. Chemical Composition. The main chemical elements contained in mineral dust, as well as volcanic ash, are silicium and oxygen, which constitute the main components of minerals and rocks in the Earth's crust and mantle.

The chemical composition of the bulk volcanic ash is mainly determined by the magma from which it is generated. Generally, three types of magma are distinguished from each other (Table 1). These types of magma have different melting points, viscosities, and typical volatile contents. The mineral composition of volcanic ash consists of about $45-75 \mathrm{wt} \%$ of silica [27]. In addition, silicate is the main component of most minerals like feldspar, olivine, pyroxene, hornblende, and biotite [29]. These minerals are formed through successive 
TABLE 1: Major types of magma.

\begin{tabular}{lccc}
\hline Magma type & $\mathrm{SiO}_{2}(\mathrm{wt} \%)$ & $T_{\text {melt }}\left({ }^{\circ} \mathrm{C}\right)$ & Viscosity and gas content \\
\hline Basaltic & $45-55$ & $1000-1200$ & Low \\
Andesitic & $55-65$ & $800-1000$ & Intermediate \\
Rhyolitic & $65-75$ & $650-1000$ & High \\
\hline
\end{tabular}

crystallisation during cooling and decompression when the magma ascends from the Earth's mantle through the Earth's crust into the conduit and subsequently into the volcanic plume [28]. During the crystallisation process, the composition of the melt is changing due to depletion of crystallised components and enrichment of remaining components driving the successive generation of different minerals, including those without silicate, such as magnetite or ilmenite.

A major difference in the mineral composition of mineral dust and volcanic ash results from chemical weathering of mineral dust, generally on geological time scales. Mineral composition changes under the influence of water, oxygen, and acids. For example, feldspar will weather to clay and ironbearing minerals can form hematite and goethite. Therefore primary iron containing minerals (e.g., amphiboles and pyroxenes) of volcanic rocks are not identified in mineral dust [30]. Further multiphase chemical modifications at the surfaces of mineral dust and volcanic ash take place during atmospheric transport (see Section 4).

\subsection{Physical Properties}

2.3.1. Size Distribution. Close to the source regions, the size distribution of mineral dust particles varies from about 0.1 to over $100 \mu \mathrm{m}$ in diameter, depending on soil characteristics and wind speed [18]. The particle size spectrum of emitted mineral dust largely controls the fraction that is transported over large distances. The coarser the particles, the faster they are deposited. However, to characterise long-range transported mineral dust, precise particle size measurements for less than about $10 \mu \mathrm{m}$ are still a challenge [31].

The size distribution of volcanic ash is greatly dependent on the formation process, which is either an explosive volcanic eruption, a phreatomagmatic eruption, or a pyroclastic density current. In addition, secondary volcanic ash clouds result from the resuspension from volcanic ash depositions on land (see Section 3.1), which should not be mixed up with coignimbrite clouds as discussed later. Explosive volcanic eruptions occur when magma containing dissolved volatiles rises in the conduit. Thereby exsolution of volatiles forms gas bubbles that grow by diffusion, decompression, and coalescence. The further the magma-gas mixture rises, the more the pressure decreases, leading to an acceleration of the mixture against gravitational and friction forces, until a continuous gas stream with clots and clasts of magma (called pyroclasts) leaves the vent explosively [1]. The explosive character of a volcanic eruption depends considerably on the viscosity of the magma. In general, most efficient fragmentation occurs during explosive eruptions where magmas of rhyolitic composition are involved because of the higher volatile content (Table 1).

Phreatomagmatic eruptions [1] are triggered by the interaction of external water with magma, for example, from a glacier as during the early phase of the Eyjafjallajökull eruption [32]. External water may also be supplied from crater lakes or even the shallow ocean during seamount volcanic eruptions [33]. Highly efficient fragmentation is caused by thermal contraction of magma due to chilling on contact with water [4]. Water initially chills the magma at the interface, which then shatters. The water penetrates the mass of shattered hot glass and is transformed into high-pressure superheated steam by a runaway process of heat transfer and further magma fragmentation, until a violent explosion results. Violent phreatomagmatic eruptions produce especially fine-grained volcanic ash.

Pyroclastic flows occur when the eruption column or lava dome collapses leading to gas and tephra flows rushing down the flanks of a volcano at high speed, which thereby also contribute to the fragmentation process through milling by the collisional processes $[1,34]$. Coignimbrite clouds can arise from pyroclastic flows when the material at the top of a pyroclastic flow gets more buoyant than the surrounding air. These convective clouds can form volcanic plumes as high as the original feeding plume and are a source of substantial amounts of fine volcanic ash as well.

As eruption conditions may be highly variable in time, all fragmentation processes can take place simultaneously. According to [2] volcanic ash particles with diameters smaller than $1 \mathrm{~mm}$ contribute about $55-97 \mathrm{wt} \%$ to the total ash content. Volcanic ash particles with diameters less than $30 \mu \mathrm{m}$ make up only a few weight percent during basaltic eruptions, whereas they can contribute $30-50 \mathrm{wt} \%$ to the total ash content during rhyolitic eruptions. However, it is the even finer particle size fraction $\left(\mathrm{PM}_{10}\right.$ and $\left.\mathrm{PM}_{2.5}\right)$ that may be carried for hundreds of kilometres before settling onto land or into the ocean.

2.3.2. Density and Surface Area. The morphology of mineral dust particles can be assumed to be spherical with a widely used particle density of $2650 \mathrm{~kg} / \mathrm{m}^{3}$ in mineral dust modelling, for example, [35]. The density of individual volcanic ash particles varies from one eruption to another and even during an eruption. Generally it lies between 2000 and $3000 \mathrm{~kg} / \mathrm{m}^{3}[28,36]$ dependent on the basaltic or rhyolitic composition, the amount of crystallisation, and porosity [37]. Due to the expansion of magmatic gases like $\mathrm{H}_{2} \mathrm{O}, \mathrm{CO}_{2}, \mathrm{SO}_{2}$, $\mathrm{H}_{2}, \mathrm{CO}, \mathrm{H}_{2} \mathrm{~S}, \mathrm{HCl}$, and $\mathrm{HF}$ [38] during an explosive and phreatomatic volcanic eruption (see Section 2.3.1), volcanic ash generally consists of vesicular particles with an undifferentiated surface texture. Generally, the specific surface area of volcanic ash is smaller than $2 \mathrm{~m}^{2} / \mathrm{g}$ [39]. However, values up to $10 \mathrm{~m}^{2} / \mathrm{g}$ have also been reported [39].

\section{Emissions into the Atmosphere, Atmospheric Load, and Subsequent Deposition}

3.1. Emissions. The notation "emission" describes the release of material from outside the atmosphere into the atmosphere, where the location outside the atmosphere represents a source for the atmosphere. Mineral dust source areas are 
generally located in semiarid or arid areas where the surface is sparsely vegetated and dry. Here, fine grained material can accumulate and be mobilised into the atmosphere by wind. Numerical models for mineral dust mobilisation usually define dust emission areas based on, for example, soil moisture [40], soil texture [13], and vegetation effects [13, 41]. Mineral dust emissions into the atmosphere are a complex, nonlinear function of both soil surface properties (size distribution of the surface soils, roughness length of erodible and nonerodible particles, and soil moisture) and meteorological conditions (wind friction velocity and precipitation). Mineral dust emissions from an erodible surface occur when the wind friction velocity exceeds a threshold value, dependent on the soil properties [42]. However, by using different assumptions, for example, erodibility factors, numerical model estimates of global mineral dust emissions vary between 1500 and $1800 \mathrm{Tg} / \mathrm{yr}[16,43,44]$. Injection heights are usually restricted to the planetary boundary layer $(2-4 \mathrm{~km})$ but may reach up to $6 \mathrm{~km}$ dependent on meteorological conditions [45]. Although mineral dust is usually considered of natural origin, it is estimated that about $30 \%$ of the mineral dust load in the atmosphere could be ascribed to human activities through desertification and land misuse. The Sahara desert is the major source of mineral dust, which subsequently spreads across the Mediterranean and European region, across the Caribbean Sea, and towards Central and North America. Additionally it plays a significant role in the nutrient inflow to the Amazon rainforest [25]. The Gobi Desert is another important source of dust in the atmosphere, which affects eastern Asia and western North America.

Volcanic ash is formed during explosive volcanic eruptions, phreatomagmatic eruptions, or pyroclastic density currents (see Section 2.3.1). On average about 20 volcanoes erupt at any given time worldwide, 50-70 volcanoes erupt throughout a year, and at least one large eruption with a Volcanic Explosivity Index (VEI, relative measure of the explosiveness of volcanic eruption; [46]) greater than 4 occurs annually [47]. The total emissions of volcanic ash into the troposphere by small volcanic eruptions with VEI $<4$ (these eruptions make up the majority in number) is estimated to be $20 \mathrm{Tg} / \mathrm{yr}$ [48], equivalent to $10 \mathrm{~km}^{3}$ when assuming a particle density of $2000 \mathrm{~kg} / \mathrm{m}^{3}$. However, these volcanic ash emissions are usually removed from the atmosphere quickly and are therefore only of local interest in the vicinity of the volcanoes up to a distance of about one hundred kilometers. Table 2 summarises ash emissions from major volcanic eruptions, lasting from a few hours to several weeks since 1900 with VEI $\geq 4$ with a tephra release ranging from 0.1 to $100 \mathrm{~km}^{3}$. It is obvious, that stronger volcanic eruptions are generally less frequent [28]. Note that before the satellite era starting about 1980 , our knowledge on volcanic eruptions with $\mathrm{VEI} \leq 4$ is probably not complete due to limited observations of remote volcanic eruptions. Dependent on meteorological conditions and the injection height of the volcanic emissions, volcanic ash from eruptions with VEI $\geq 4$ may be transported over thousands of kilometres in the atmosphere [49]. Therefore, volcanic ash, although released sporadically during volcanic eruptions, is an abundant atmospheric species.
It should be considered as well that fresh volcanic ash may be remobilised into the atmosphere from ash deposits on land, similar to what is observed for mineral dust, particularly in arid and semiarid regions. This contradicts with the general assumption that volcanic ash environmental and climate effects are restricted only to the duration of a volcanic eruption with time scales of days to weeks. Reference [9], for example, reports such posteruptive volcanic ash clouds being transported over the Patagonian desert for several months to years after the 1991 eruption of Mt. Hudson in Chile (Figure 2). Following the recent eruption of Eyjafjallajökull in Iceland during April/May 2010, volcanic ash remobilisation created poor air quality and health concerns for the local population for several months [10-12]. References $[8,9]$ also report volcanic ash from resuspensions events from the Katmai/Novarupta eruption in 1912, which typically occur in the fall before snowfall. The June 6-8, 1912 Katmai/Novarupta eruption was the largest volcanic eruption in the 20th Century and produced volcanic ash deposits of 1-10 meters around the volcano. A lack of snow combined with strong northerly winds is able to mobilise the hundred years old volcanic ash into the atmosphere even nowadays (Figure 2).

3.2. Atmospheric Load. Atmospheric concentrations of mineral dust and volcanic ash are subject to considerable temporal and spatial variability. Seasonal variability, for example, rainy and dry seasons, determines to a great extent the mineral dust load in the atmosphere, whereas volcanic ash atmospheric load is mainly dependent on the occurrences of sporadic and usually unpredictable volcanic eruptions.

Measurements in the Sahelian belt of West Africa [50] during 2006 to 2008 reveal median daily mineral dust concentrations of around $80 \mu \mathrm{g} / \mathrm{m}^{3}$ with about $40 \%$ exceeding $100 \mu \mathrm{g} / \mathrm{m}^{3}$ and less than $3 \%$ exceeding $500 \mu \mathrm{g} / \mathrm{m}^{3}$. The maximum measured daily concentrations range is between 2250 and $4020 \mu \mathrm{g} / \mathrm{m}^{3}$ [50]. The European standard for air quality (daily mean PM10 concentration of $50 \mu \mathrm{g} / \mathrm{m}^{3}$ should not be exceeded for more than 35 days per year) is exceeded in this area by mineral dust aerosols about 200 days per year [50]. In the northern part of the Taklamakan desert a higher interannual variability with maximum daily mineral dust concentrations of $645-3800 \mu \mathrm{g} / \mathrm{m}^{3}$ was measured between 2001 and 2004 [51]. An even higher variability is reported for the Inner Mongolia region [52] with PM10 concentrations of $190-9625 \mu \mathrm{g} / \mathrm{m}^{3}$. Downwind from main mineral dust sources, concentrations are usually smaller, for example, on Cape Verde Islands between 65 and $264 \mu \mathrm{g} / \mathrm{m}^{3}$ during mineral dust transport episodes [53].

During the eruption of Eyjafjallajökull on Iceland in 2010, maximum ash concentrations up to $4000 \mu \mathrm{g} / \mathrm{m}^{3}$ are reported from measurements of the volcanic ash cloud spreading over Europe [54, 55], exceeding the threshold for safe aviation $\left(2000 \mu \mathrm{g} / \mathrm{m}^{3}\right)$. Daily mean near surface concentrations reached up to $400 \mu \mathrm{g} / \mathrm{m}^{3}$ in Scandinavia during the eruption [54]. Close to Eyjafjallajökull, the maximum daily average near surface concentration exceeded $1230 \mu \mathrm{g} / \mathrm{m}^{3}$ during the ongoing eruption, but also after the eruption stopped, maximum daily average concentration reached 
TABLE 2: Tephra mass release in DRE (Dense Rock Equivalent) of well-known volcanic eruptions since 1900 given for VEI values from 4 to 6 in three mass ranges: $0.1-1 \mathrm{~km}^{3}, 1-10 \mathrm{~km}^{3}$, and $10-100 \mathrm{~km}^{3}$ ([47]; http://www.volcano.si.edu/).

\begin{tabular}{|c|c|c|c|}
\hline \multirow[t]{2}{*}{$0.1 \mathrm{~km}^{3}$} & $1 \mathrm{~km}^{3}$ & $10 \mathrm{~km}^{3}$ & \multirow[t]{2}{*}{$100 \mathrm{~km}^{3}$} \\
\hline & $\mathrm{VEI}=5$ & $\mathrm{VEI}=6$ & \\
\hline \multicolumn{4}{|l|}{$\begin{array}{l}\text { Nabro } 2011 \text { and Puyehue-Cordón Caulle } \\
2011\end{array}$} \\
\hline \multicolumn{4}{|l|}{ Grimsvötn 2011 and Merapi 2010} \\
\hline \multicolumn{4}{|l|}{$\begin{array}{l}\text { Eyjafjallajökull } 2010 \text { and Sarychev Peak } \\
2010\end{array}$} \\
\hline \multicolumn{4}{|l|}{ Kasatochi 2008 and Chaiten 2008} \\
\hline \multicolumn{4}{|l|}{ Reventator 2002 and Ulawun 2000} \\
\hline \multicolumn{4}{|l|}{ Lascar 1993 and Mt. Spurr 1992} \\
\hline Kelud 1990 and Kiluchevkoi 1987 & Mt. Hudson 1991 & Pinatubo 1991 & \\
\hline \multicolumn{4}{|l|}{$\begin{array}{l}\text { Chikurachki } 1986 \text { and Mount Augustine } \\
1986\end{array}$} \\
\hline Colo 1983 and Galunggung 1982 & El Chichon 1982 & & \\
\hline \multicolumn{4}{|l|}{ Pagan 1981 and Alaid 1981} \\
\hline Mount Augustine 1976 and Tolbachik 1975 & Mt. St. Helens 1980 & & \\
\hline \multicolumn{4}{|l|}{ Volcan de Fuego 1974 and Tiatia 1973} \\
\hline \multicolumn{4}{|l|}{ Fernandina 1968 and Mount Awu 1966} \\
\hline \multicolumn{4}{|l|}{ Kelud 1966 and Taal 1965} \\
\hline $\begin{array}{l}\text { Shiveluch } 1964 \text { and Carran-Los Venados } \\
1955\end{array}$ & Agung 1963 & & \\
\hline Mount Spurr 1953 and Bagana 1952 & Bezymianny 1956 & & \\
\hline \multicolumn{4}{|l|}{ Kelud 1951 and Mount Lamington 1951} \\
\hline \multicolumn{4}{|l|}{ Ambrym 1950 and Hekla 1947} \\
\hline \multicolumn{4}{|l|}{ Sarychev Paek 1946 and Avachinsky 1945} \\
\hline \multicolumn{4}{|l|}{ Paricutin 1943-1952 and Suoh 1933} \\
\hline $\begin{array}{l}\text { Volcan De Fuego } 1932 \text { and Mont Aniakchak } \\
1931\end{array}$ & Kharimkotan 1933 & & \\
\hline Kliucheskoi 1931 and Komagatake 1931 & Cerro Azul 1932 & & \\
\hline \multicolumn{4}{|l|}{ Komagatake 1929 and Avachinsky 1926} \\
\hline \multicolumn{4}{|l|}{ Raikoko 1924 and Manam 1919} \\
\hline Kelud 1919 and Agrhan 1917 & Katla 1918 & & \\
\hline \multicolumn{4}{|l|}{ Tungurahua 1916 and Sakurajima 1914} \\
\hline Mount Lolobau 1911 and Grimsvötn 1903 & Colima 1913 & Katmai/Novarupta 1912 & \\
\hline Monut Pelee 1902 & Ksudach 1907 & St. Maria 1902 & \\
\hline
\end{tabular}

more than $1000 \mu \mathrm{g} / \mathrm{m}^{3}$ during resuspension events [12]. Volcanic ash concentrations within the volcanic eruption plume are expected to be even higher. However, measurements are difficult to obtain as saturation levels are reached by remote sensing instruments and direct measurements destroy measurement equipment and are too dangerous for humans to approach too close to the eruption. Altogether, the magnitudes of maximum atmospheric concentrations that may be reached during mineral dust storms and volcanic eruptions are relatively similar, although for volcanic eruptions with VEI $\geq 4$ higher atmospheric ash concentrations are expected.

3.3. Deposition. Mineral dust and volcanic ash are removed from the atmosphere by gravitational settling, turbulent dry deposition, and wet scavenging by rain called wet deposition
[56]. Dry and wet aggregation of volcanic ash belongs per definition to the removal processes of dry and wet deposition [6]. However, because of their specialty they are discussed separately later. The ratio of dry-to-wet deposition differs considerably in mineral dust model estimates [19], with wet deposition over the ocean ranging from $30 \%$ to $95 \%$ of the total mineral dust deposition [18]. It should be noted that all uncertainties of the global mineral dust cycle, including emissions (see Section 3.1) and transport in the atmosphere, are summed up in the distribution and amount of deposition fluxes. Mineral dust deposition to ice cores reveals an up to factor 100 difference between cold and warm periods in the geological past [16], for example, much higher deposition during the Last Glacial Maximum, 21,000 years before present, compared to the present-day climate. 


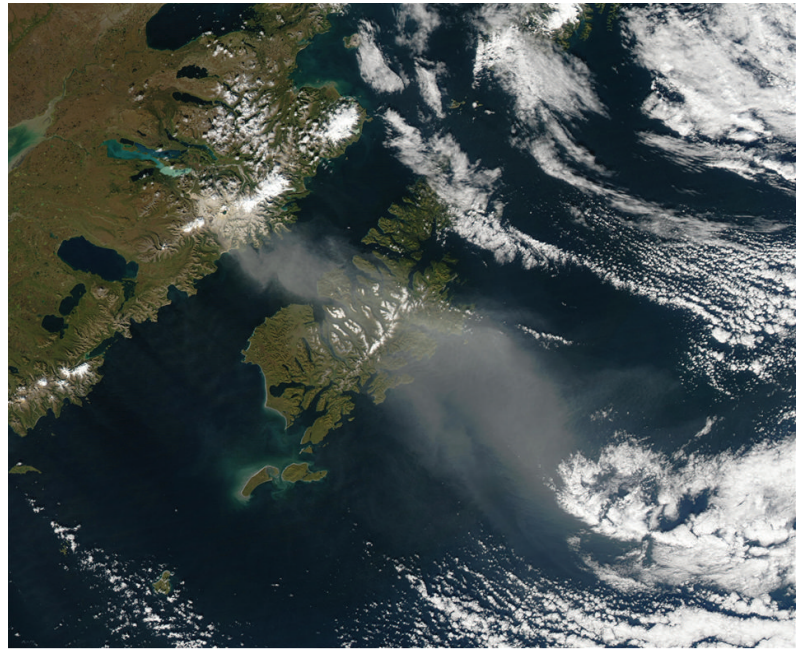

(a)

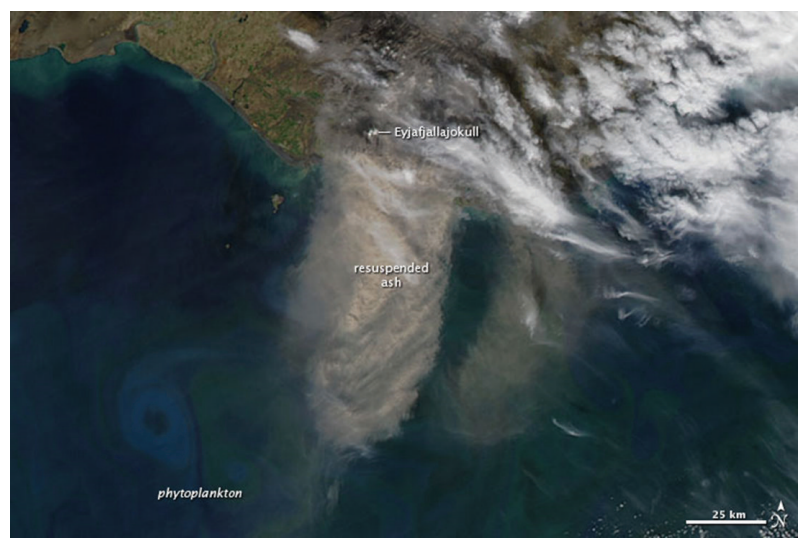

(c)

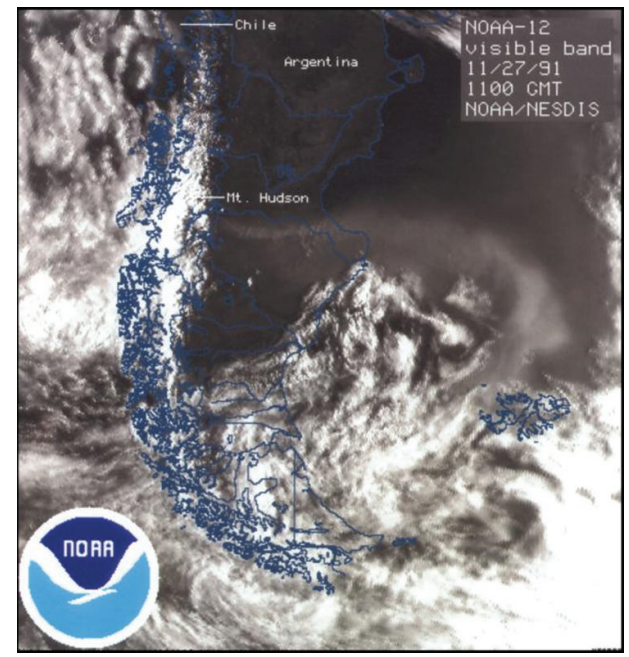

(b)

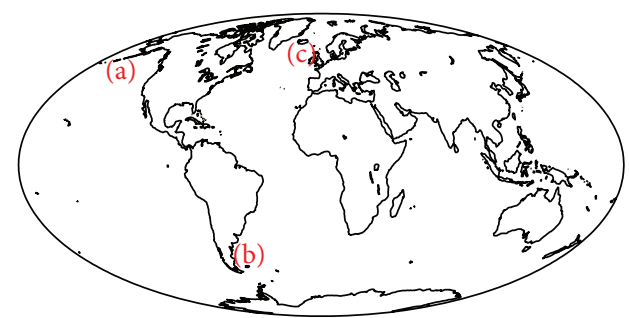

(d)

FIGURE 2: Volcanic ash resuspension event as seen from satellite: (a) September 21, 2003: Katmai/Novarupta, Alaska; (b) November 27, 1991: Cerro Hudson, Chile; (c) May 27, 2010: Eyafjallajökull, Iceland; (d) approximate location of (a)-(c). Courtesy of NASA.

Reference [57] estimated the millennial scale flux of volcanic ash into the Pacific Ocean based on the marine sediment core data $[58,59]$ to be about $128-221 \mathrm{Tg} / \mathrm{yr}$. This represents a conservative estimate, as already one volcanic eruption of VEI = 4 like Kasatochi in 2008 [60] can produce higher deposition fluxes. The estimated millennial volcanic ash flux is comparable to the mineral dust flux into the Pacific Ocean of around $100 \mathrm{Tg} / \mathrm{yr}$ [16]. So far, however, the importance of volcanic eruptions on climate, for example, by modifying the biogeochemistry of the surface ocean, has gained limited attention compared to the much better investigated effects of mineral dust. The amount of volcanic ash and bioavailable iron attached to the ash surface deposited into the ocean during episodic large volcanic eruptions may exceed the annual mineral dust flux by far. Reference [61], for example, estimated that iron deposition of the Mt. Hudson's volcanic eruption in Chile during August 12-15, 1991 is equivalent to $\sim 500$ years of Patagonian iron dust fallout.

Gravitational settling of volcanic ash has been observed to exceed the terminal settling velocity of single ash particles $[6,62]$. This is explained by the formation of aggregates in the volcanic plume, as well as under more diluted conditions in the volcanic cloud [63-65]. Volcanic ash aggregation therefore represents a process that increases sedimentation and reduces atmospheric volcanic ash concentration during long-range transport. However, key aggregate formation processes and basic classifications are topics of ongoing debate. Several important questions remain unanswered up to now. Is aggregation driven primarily by hydrometeor formation? How does aggregation vary in time and space? What is the role of electrostatic charge and "secondary minerals"? How do instabilities (e.g., mammatus) change deposition rates? What proportion of fine-grained ash ends up in aggregates? Where does particle aggregation mainly occur (e.g., vertical plume, horizontal cloud, or during atmospheric sedimentation)? A better understanding of volcanic ash aggregation will be necessary to improve the modelling of volcanic ash dispersion and deposition.

\section{Atmospheric Processing}

4.1. Chemical Processing in Volcanic Plumes. Before atmospheric processing occurs at ambient temperatures, volcanic ash undergoes extreme temperature gradients (from about 
$1000^{\circ} \mathrm{C}$ to less than $0^{\circ} \mathrm{C}$ ) in extreme short periods of time (few minutes) in the volcanic eruption plume $[1,66,67]$, which is expanding vertically into the atmosphere from the vent to the level of neutral buoyancy (Figure 1). Besides fragmentation processes taking place here (see Section 2.3.1), quenching represents an important process in the production of the glass material contained in volcanic ash together with minerals formed by incomplete crystallisation reactions (see Section 2.2). Intensive lightning in the volcanic eruption plume is an often-observed phenomenon $[68,69]$ due to vertically separated regions of oppositely charged volcanic ash particles. Aggregation processes of volcanic ash (see Section 3.3) may be affected by the charged volcanic ash particles. Until now, the temperature and ionising effects of lighting strokes on volcanic ash chemical composition have not been investigated. A number of potentially important processes for physical-chemical modifications of volcanic ash surfaces, without considering lightning, are discussed in the literature, as summarised below. Volcanic eruption plumes cool significantly during rise from about $1000^{\circ} \mathrm{C}$ at the vent to ambient temperature leading to various homogeneous and heterogeneous chemical and microphysical modifications on the ash surfaces. During volcanic eruptions, large amounts of volatiles $[1,38,66]$ are released into the atmosphere along with volcanic ash. Through the interaction between these gases and secondary aerosols produced from these gases with volcanic ash within the eruption plume, it is assumed that soluble compounds are produced on the volcanic ash surfaces [70-72], scavenging up to $30 \%-40 \%$ of the sulfur and $10 \%-20 \%$ of the chlorine released from volcanic eruptions $[70,73]$. Reference [71] introduced the idea that scavenging of volatiles by ash within eruption plumes occurs in three temperature-dependent zones: (1) the "salt formation zone" representing the hot core of the eruption plume where sulfate and halide salt aerosols, which were formed at near magmatic temperatures, are adsorbed onto ash particles; (2) in the "surface adsorption zone" halogen gases react directly with the surface of ash during the cooling of the plume until temperatures of about $700^{\circ} \mathrm{C}$ are reached; (3) the "condensation zone" is characterised by the formation of sulfuric and halogen acids at temperatures below $338^{\circ} \mathrm{C}$.

Leaching experiments with pristine volcanic ash in water have been performed for decades [74] revealing the release of various sulfate and halide compounds in addition to biologically relevant elements such as $\mathrm{N}, \mathrm{P}, \mathrm{Si}, \mathrm{Fe}, \mathrm{Cd}, \mathrm{Co}$, $\mathrm{Cu}, \mathrm{Mn}, \mathrm{Mo}, \mathrm{Pb}$, and $\mathrm{Zn}$ [75-77]. Several studies suggest adsorption of volcanic salts on volcanic ash surfaces as the main mechanism for the production of soluble compounds on volcanic ash [78, 79]. Other studies emphasise that condensation of sulfuric acid onto volcanic ash may drive dissolution reactions, thereby providing the source of the soluble cations measured in ash leachates [70]. Different to these assumptions, measurements of [80] point to a rapid acid dissolution of the ash surface material within eruption plumes followed by precipitation of secondary minerals and salts at the ash-liquid interface. Reference [80] assumes adsorption of volcanic salts to represent a process of minor importance. Reference [81] reports about the hightemperature scavenging of volcanic $\mathrm{SO}_{2}$ by volcanic ash with potential important modifications of the ash surfaces under cooler conditions. Only a few of these aspects have been explored so far by using complex plume models, for example, [82]. Despite the progress made in recent years, the physical-chemical mechanisms, which govern the modification of the surface composition of volcanic ash during its transit through the volcanic eruption plume, where large temperature (from about $1000^{\circ} \mathrm{C}$ to ambient temperature) and chemical gradients prevail, are poorly understood [83] and require further investigations. A further understanding of these processes under such extreme conditions may also help to increase our knowledge of atmospheric processing of mineral dust, even though mineral dust modifications are restricted to ambient temperatures.

4.2. Chemical Processing at Ambient Atmospheric Temperatures. After a volcanic plume reaches neutral buoyancy conditions, the volcanic cloud spreads out more horizontally (Figure 1). In the volcanic cloud further chemical modifications of volcanic ash surfaces at ambient temperatures, for example, during long-range atmospheric transport at high $\mathrm{SO}_{2}$ /sulfate concentrations, may also occur. Although the volcanic emissions are already diluted in the volcanic cloud, the acidic environment in volcanic clouds, which is dependent on the volcanic release rate of $\mathrm{SO}_{2}[84,85]$ (Figure 3) and other acidic substances like $\mathrm{HCl}$ and $\mathrm{HF}$, may exceed by far that for mineral dust acid processing in anthropogenic polluted air masses [86]. However, volcanic ash, volcanic gases, and their oxidation products (e.g., $\mathrm{H}_{2} \mathrm{SO}_{4}$ ) are not necessarily released into similar atmospheric altitudes during a volcanic eruption (e.g., 1991 eruption of Pinatubo; [87]), resulting in different altitudes for the major dispersion pathways of volcanic ash and gases and limited acid processing during atmospheric transport. Furthermore, due to rapid sedimentation, a separation of volcanic ash particles from volcanic gases and secondary aerosols like sulphate occurs within some hours to days (dependent on the volcanic ash size distribution), even when the eruption height for all volcanic emissions is very similar as what was observed during the eruption of Kasatochi in 2008 [49].

In contrast, volcanic ash, which is remobilised from ash deposits, can be assumed to undergo very similar atmospheric processing as mineral dust. The importance of photochemistry for mineral dust under atmospheric conditions is highlighted in several studies [22, 23, 88, 89]. Mineral dust particles can act as a sink for $\mathrm{SO}_{2}$, thus enabling the formation of sulfate on the mineral dust surfaces [90]. When mineral dust concentrations are low, they may trigger the nucleation of new sulfate particles via a series of photochemical reactions involving the mineral dust surface [91]. Metal oxides present in mineral dust act as atmospheric photocatalysts promoting the formation of gaseous $\mathrm{OH}$ radicals, which initiate the conversion of $\mathrm{SO}_{2}$ to $\mathrm{H}_{2} \mathrm{SO}_{4}$ in the vicinity of dust particles. Comparable results for volcanic ash have also been measured (Dupart, personal information, 2011).

At ambient temperature, when clouds are present in the atmosphere, cloud processing is assumed to provide the main mechanism for the uptake of acid gases in the atmosphere by aerosols in general [56], including mineral dust [92-94] 


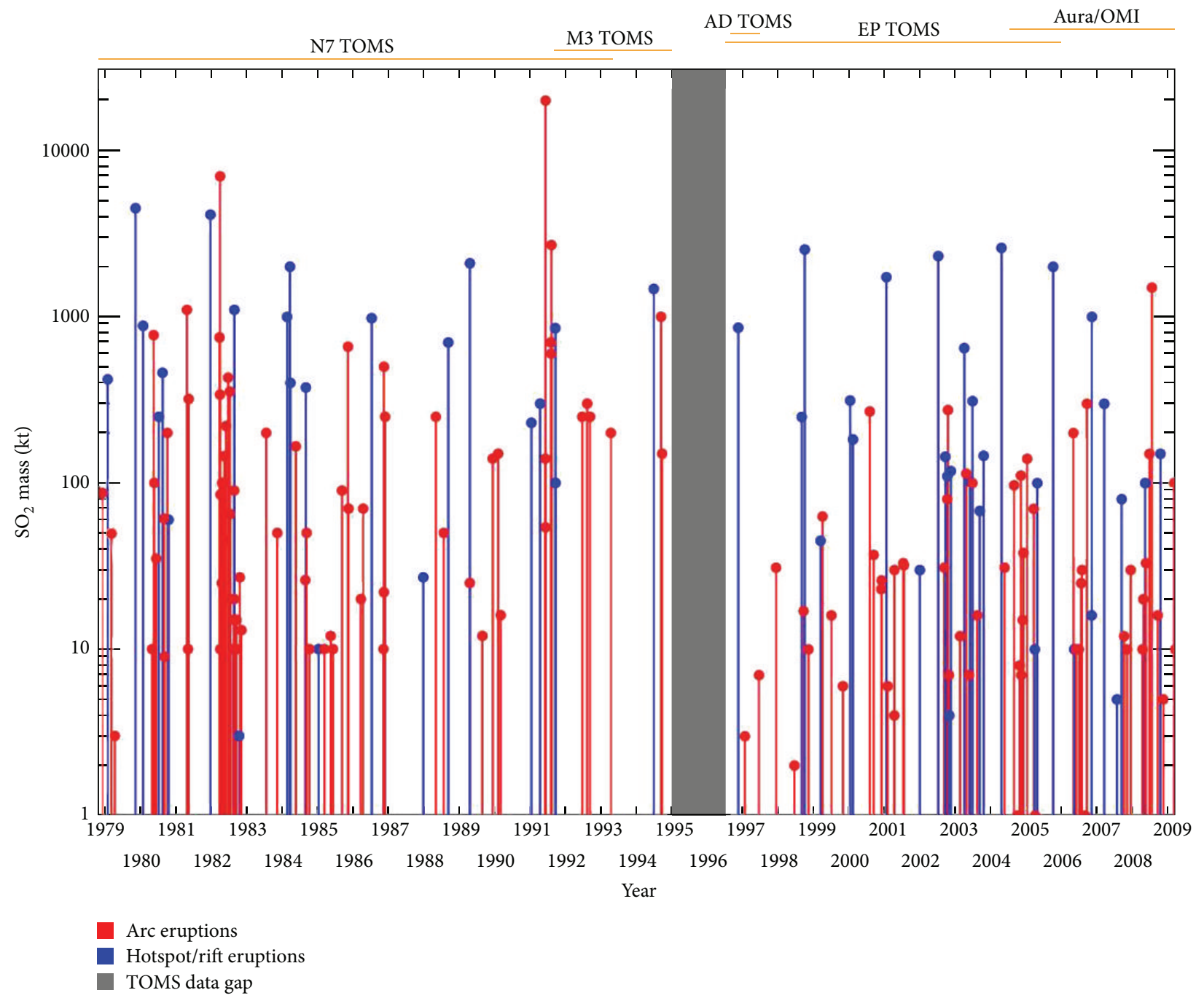

FIGURE 3: $\mathrm{SO}_{2}$ emissions from major volcanic eruptions observed from satellite. Arc eruptions with $\mathrm{SO}_{2}$ emissions exceeding 1000 kt: Mt. St. Helens 1980 (slightly less), Alaid 1981, El Chichon 1982, Mt. Pinatubo 1991, Mt. Hudson 1991, Raboul 1994, and Kasatochi 2008 (Courtesy of NASA).

and volcanic ash particles [95]. During atmospheric transport of mineral dust and volcanic ash particles, clouds often evaporate leaving only a thin film of aqueous electrolyte around each particle [56]. This film of aerosol water is very acidic compared to the cloud droplet, reaching $\mathrm{pH}$ values of 2 or even lower [86, 96]. As clouds can form and evaporate several times [56], five to ten cycles of $\mathrm{pH}$ alternation in the aqueous film around mineral dust and volcanic ash particles can occur before these particles are deposited via wet deposition or sedimentation out of the atmosphere [30]. Atmospheric processing is widely accepted to represent a key process for iron solubility in mineral dust $[30,97,98]$. Limited understanding of these processes hinders the development of accurate biogeochemical models predicting the impact of mineral dust and volcanic ash deposition on the chemistry of trace metals in the surface ocean and ultimately on the global carbon cycle (see Section 5.4.3).

Atmospheric processing of mineral dust and volcanic ash particles at freezing temperatures is a process, which has been rarely studied. However, indications for increased iron solubility are presented [99]. Physical-chemical modifications of volcanic ash surfaces in the volcanic plume and/or volcanic cloud may also affect volcanic ash aggregation (see Section 3.3) [6], which in turn influences particle sedimentation from the plume and during long-range transport, thereby affecting the residence time of volcanic ash in the atmosphere.

Atmospheric and volcanic processing with modifications of the surface chemical composition of mineral dust and volcanic ash particles has implications on their behaviour to act as cloud condensation or ice nuclei (CCN or IN; see Section 5.4.2) and releasing nutrients (in particular iron) on contact with seawater (see Section 5.4.3). Observational studies in the field and the laboratory have confirmed that mineral dust and volcanic ash particles can act as CCN or IN, in particular, after being aged in the atmosphere $[20,21,95,100-102]$. If the surface of volcanic ash has been partially dissolved, water uptake may be favoured [39], 
thereby explaining the ability of volcanic ash to act as cloud condensation and ice nuclei.

For the sake of completeness, mechanical and biogeochemical weathering that takes place at the Earth's surface under atmospheric conditions is mentioned here as well. These processes are important in the generation of mineral dust and decomposition of volcanic ash on geological time scales [103]. However, they are beyond the scope of this review. The interested reader is referred to the extensive literature, for example, [104], which provides detailed information on weathering processes and important control variables, such as water, oxygen, and acids, as well as lithology, morphology, soil, ecosystems land use, temperature, and runoff.

\section{Environmental and Climate Impacts}

5.1. Human Health. Aeolian dust episodes represent a major health concern for humans due to elevated atmospheric concentrations (see Section 3.2). In urban centres in Asia, mineral dust episodes have become a growing concern for the health of populations and ecosystems due to mixing with pollution aerosols $[105,106]$. With higher levels of exposure, widespread chronic respiratory and lung diseases, asthma, allergic alveolitis, and eye irritations are well-documented health effects [107]. Human exposure to high volcanic ash concentrations may create similar health effects as those related with mineral dust. However, due to its sharp surface structures, small ash particles have additional mechanical effects; for example, they can abrade the front of the eye under windy conditions [108] (Horwell and Baxter, 2006) and lead to silicosis in the worst case.

5.2. Aviation. Strong mineral dust storms mainly affect takeoff and landing of aircraft due to poor visibility. However, aircraft can operate in environments with high mineral dust concentration without any engine problems. Mineral dust which typically melts at temperatures of around $1700^{\circ} \mathrm{C}$ does not melt when it is ingested in jet engines. However, jet engines may have problems with volcanic ash as the melting temperatures are at or below the operating temperatures of high-performance jet engines, which are around $1400^{\circ} \mathrm{C}$ [109]. The molten material deposited on the cooler parts of the engines can cause flame-outs, which may also result from glass shards when temperature exceeds their glass transition temperature. 129 flights in the last 60 years were affected by volcanic ash [110], for example, during the eruption of Galunggung, Indonesia (1982) or Redoubt, Alsaka (1989/1990). In nine cases, one or more engines temporarily failed due to the melting of ash in the jet engine turbine [110]. To prevent dangerous flights in the presence of volcanic ash, Volcanic Ash Advisory Centres (VAACs) have been installed with the mandate to regularly publish warnings on the location of volcanic ash in the atmosphere. After the eruption of Eyjafjallakökull in Iceland in 2010, a growing demand developed, suggesting that VAACs should not only follow the zero tolerance rule, but also provide absolute volcanic ash concentrations $[32,111]$, with a preliminary threshold of $2 \mathrm{mg} / \mathrm{m}^{3}$ for safe aircraft operation.
5.3. Soil Fertilisation. Heavy volcanic ash or mineral dust deposition completely buries vegetation and soil. Plant survival is dependent on deposit thickness, chemistry, compaction, rainfall, and duration of burial. Slight deposition of volcanic ash and mineral dust can affect vegetation and soil positively and negatively. Although thin volcanic ash fall inhibits transpiration and photosynthesis and alters growth, buried plants may survive [37]. A positive effect is attributed to mineral dust originating from the Sahara desert, which is regularly transported across the Atlantic Ocean and is argued to represent the main mineral fertiliser of the Amazon region [25]. A positive effect of volcanic ash deposition is an increase in agricultural production due to mulching, for example, following the 1980 Mount St. Helens eruption [112]. Other positive effects are due to the leaching of nutrients released from volcanic ash [28], for example, following the 1995/96 Mt. Ruapehu eruption. In particular, nutrient-poor soils benefit from volcanic ash leaching; however, soluble toxic elements may also be washed-out [37].

\subsection{Climate}

5.4.1. Direct Radiative Effects. Short-term effects during mineral dust storms, volcanic eruptions, and volcanic ash resuspension events considerably reduce visibility and solar irradiation reaching the Earth's surface, whereas long-term effects occur in a more diluted environment. These effects can be measured by an increase in atmospheric optical depth, represented by enhanced absorption and/or scattering of solar and thermal radiation and modifications in surface temperature. During the first two days following the 1980 eruption of Mount St. Helens, [113] reported a decrease in daytime surface temperature of $8^{\circ} \mathrm{C}$ induced by volcanic ash absorption of solar radiation in the ash affected area downwind of Mt. St. Helens. Here, the colour of volcanic ash pays an important role; low-Si, high-Fe ash tends to develop a dark brown and black colouration, whereas high-Si ash with low Fe ash tends to appear pale and white coloured [37]. The colour of volcanic ash is also an important factor for the modification of the surface albedo for volcanic ash deposits covering the soil. Reference [112] estimated that the lightcoloured volcanic ash from Mount St. Helens reflected two to three times more incoming solar radiation than ash-free soils. In contrast, dark-coloured ash will decrease the surface albedo. A modification of the surface albedo will also occur after volcanic ash deposition on snow or ice. In most cases a reduction is observed, although [114] argues that reflectivity measurements of dry volcanic ash can show albedo values as high as snow. Therefore, large areas covered by volcanic ash may have considerable implications for climate [114].

Direct radiative effects of mineral dust have been studied widely [13, 19, 31, 115-117]. Reference [111] compared optical properties of volcanic ash from the Ejyafjallajökull eruption in 2010 with Sahara dust. Although the optical properties of volcanic ash and mineral dust are relatively similar, the imaginary part of the refractive index shows weaker absorption and drops stronger between the blue and red parts of the spectrum for mineral dust when compared with volcanic ash. Another difference in optical properties was observed for the 
polarisation properties, with slightly stronger forward and lower backward scattering for volcanic ash. These differences allow discrimination between mineral dust and volcanic ash during, for example, lidar measurements [118]. However, atmospheric processing (see Section 4) may modify the radiative properties of both, mineral dust [119] and volcanic ash, although further investigations are needed.

Due to the relatively short residence time of mineral dust and volcanic ash in the atmosphere (in the order of a few days), their direct radiative effects (and indirect radiative effects; see Section 5.4.2) exhibit a high temporal and spatial variability, with major effects around the main source regions and the main transport pathways from a few kilometers to some thousand kilometres. In these regions, however, the direct radiative effects of mineral dust and volcanic ash may be dominant.

5.4.2. Indirect Radiative Effects. With about $60 \%$ of the Earth being cloud covered, clouds represent an important factor in regulating the Earth's radiation budget [120]. It has been estimated that a $5 \%$ increase of the shortwave cloud forcing could compensate the radiative effect due to increased greenhouse gases between the years 1750-2000 [107]. Cloud formation, lifetime, and radiative properties are affected by aerosols. These so-called indirect aerosol effects are related to changes of the cloud droplet and ice spectrum.

In general, a greater quantity of cloud droplets are formed with typically smaller size if more aerosols are available to act as cloud condensation nuclei (CCN). High cloud droplet number concentrations (CDNC) reduce the diffusional droplet growth. Therefore droplet sizes cannot be reached which are large enough for an efficient growth by droplet collision. Thus, changes in CDNC can influence cloud albedo (first indirect aerosol effect) [121], cloud lifetime, and precipitation formation (second indirect aerosol effect) [122]. In the tropics, the modification of precipitation formation in deep convective clouds is of special importance. The local effect near the aerosol source regions may lead to suppression of precipitation. However, as more liquid water and water vapour stays in the atmosphere, precipitation will be formed elsewhere and the potential of flooding and erosion is increased. Global circulation can be influenced by the release of latent heat due to condensation of water vapour. Therefore, aerosols including mineral dust and volcanic ash, which act as cloud condensation $[20,123]$ and ice nuclei (see later), have the potential to affect the Earth's radiation budget, the hydrological cycle, and regional or even global circulation [124]. Satellite observations in the South Atlantic and North Pacific [123] show that either natural degassing or weakly explosive volcanoes affect low marine stratocumulus for up to $1300 \mathrm{~km}$ downwind by decreasing the effective radius of droplets and increasing visible brightness, which may add cloud cover in otherwise cloudless areas.

Super-cooled clouds are abundant in the atmosphere, which contain metastable water that freezes as soon as suitable ice nuclei are available. In the presence of particulate material, such as mineral dust, volcanic ash, or pollen $[95,100,125-130]$, it may undergo heterogeneous nucleation, where freezing may be initiated at significantly lower supersaturations and higher temperatures than in the case of homogeneous freezing [125]. Upon glaciation, the size distribution and the lifetime and radiative forcing of the clouds are modified. A negative correlation between super-cooled clouds (at $-20^{\circ} \mathrm{C}$ ) and the occurrence of mineral dust has been found by [131], likely due to glaciation by dust. Reference [100] measured ice formation in the presence of fine volcanic ash particles between about 250 and $260 \mathrm{~K}$. During the Eyjafjallajökull volcanic eruption on Iceland in spring 2010, lidar measurements over Europe clearly observed volcanic ash having an impact on cloud glaciation [130], and in central Germany the highest IN number concentrations within a two year record of daily IN measurements were measured [95]. Also in Israel, about $5000 \mathrm{~km}$ away from Eyjafjallajökull, INs were as high in spring 2010 as during desert dust storms. Reference [95] showed that aging increased the ice nucleating ability of the volcanic ash during its transport in the atmosphere (see Section 4.2).

5.4.3. Ocean Fertilisation. In the past 20 years, iron-enrichment experiments ranging from bottle incubations to open-ocean amendment studies in regions of $50-100 \mathrm{~km}^{2}$ have demonstrated that iron supply stimulates phytoplankton growth in High-Nutrient-Low-Chlorophyll (HNLC) waters [132]. Thereby, the surface ocean is fertilised with iron, which affects marine primary production (MPP), phytoplankton community structures, and subsequently has an impact on higher trophic levels of the oceanic food-web (zooplankton, fish). Through the conversion of $\mathrm{CO}_{2}$ to organic carbon and the sinking of parts of this organic matter into the deep ocean, the process referred to as the "biological pump" is activated and atmospheric $\mathrm{CO}_{2}$ concentrations can be modified. However, it has been difficult to quantify export production via subsurface storage of carbon. The details of the "iron hypothesis" [24] and the possible magnitude of its effect on the global carbon cycle are subject of intense international debate, particularly in connection with climate engineering.

Ocean fertilisation by mineral dust has been studied extensively, as mineral dust has long been assumed to be the main component of atmospheric deposition of minerals into the open ocean [15]. A significant correlation of dust with climate indicators is found in paleorecords such as ice cores [133-135]. In the NE Pacific Ocean, the supply of iron from dust sources occurs episodically, for example, $[136,137]$, which is dependent on dust storm frequency and atmospheric circulation. For the Southern Ocean, an important multiproxy dataset was recently presented from a marine sediment core in the sub-Antarctic Atlantic [138]. A close correlation was observed between iron input and marine export production, implying that the process of ion fertilisation on marine biota was a recurred process operating in the sub-Antarctic region over the glacial/interglacial cycles of the last $1.1 \mathrm{Ma}$. A 25\%-50\% decrease in $\mathrm{CO}_{2}$ observed during glacial maxima is attributed to mineral dust $[132,139]$.

Volcanic ash deposition into the ocean represents another external and largely neglected source of iron. However, its significance and impact on climate has long been considered negligible. The major climate forcing effect following volcanic eruptions is widely assumed to occur due to the reduction 
of solar radiation through volcanic sulfate aerosols [5]. In contrast to volcanic gases and aerosols, volcanic ash is removed from the atmosphere much faster after an eruption. Recent work, however, showed that volcanic ash modifies the biogeochemical processes in the surface ocean $[57,60,76$, $140,141]$ thereby directly affecting climate. When airborne volcanic ash is deposited in the surface ocean, it may release trace species upon contact with seawater [75, 142]. Volcanic ash, though released sporadically, can therefore play a similar role as mineral dust. Other trace metals contained in volcanic ash such as zinc or copper may have both, fertilising or toxic effects on phytoplankton [140].

The first direct evidence for iron fertilisation in an HNLC ocean area by volcanic ash emerged after the eruption of the Kasatochi volcano, situated on the Aleutian Islands in August 2008. Atmospheric and oceanic conditions in the NE Pacific were ideal for generating a massive and largescale phytoplankton bloom, which was observed by satellite instruments [60], confirmed by insitu measurements [143, 144] and ocean biogeochemical modelling [145]. In 2010, it was speculated that the population of sockeye salmon returning to the Fraser River in Canada which was the largest for decades was associated with the fertilisation of the NE Pacific Ocean by Kasatochi ash in 2008 [146]. However, the effect of volcanic ash on salmon populations is discussed controversially; for example, the analysis of [147] rejects the hypothesis of [146].

After the eruption of Kasatochi in 2008 on the Aleutian Islands, atmospheric $\mathrm{CO}_{2}$ decreased slightly by $\sim 0.01 \mathrm{PgC}$ as diatoms and mesozooplankton increased export of organic carbon from the surface to the deeper ocean [143]. This carbon sequestration was negligible compared to the rate at which fossil fuel emissions are rising (7-9 Pg C/yr; [107]). While the volcanic ash flux from Kasatochi of $0.2-0.3 \mathrm{~km}^{3}$ [60] was relatively small, there is abundant evidence for regular volcanic ash emissions into the atmosphere (see Section 3.1, Table 2). Although strong volcanic eruptions with VEI $\geq 5$ are rare and not necessarily close to an oceanic HNLC area, they are argued to have affected MPP and atmospheric $\mathrm{CO}_{2}$ on geological time scales [148-152]. In addition, volcanic ocean fertilisation is not restricted to HNCL areas, as reported by [153] for the Mediterranean Sea or by [141] for the North Atlantic Ocean. However, all these effects are discussed controversially.

Reduced atmospheric $\mathrm{CO}_{2}$ concentrations were observed in the years following the 1991 Pinatubo eruption [154, 155]. Reference [156] argued that this was the consequence of increased vegetation photosynthesis induced by the presence of a volcanic sulfate aerosol layer in the atmosphere. Notably, [154] Sarmiento (1993) suggested that the atmospheric $\mathrm{CO}_{2}$ drawdown was the result of ocean fertilisation by Pinatubo ash. While the 1991 Pinatubo eruption released 5-6 km ${ }^{3}$ of ash (about 30 times the volume of ash emitted by Kasatochi in 2008), a percentage limited amount fell into the iron-limited Southern Ocean. However, the eruption of Mt. Hudson around the same time deposited approximately $1.1 \mathrm{~km}^{3}$ of ash into the iron-limited Atlantic sector of the Southern Ocean [157]. Surprisingly, this ash deposition event has never been evoked to explain the decrease in atmospheric $\mathrm{CO}_{2}$ concentration. Furthermore, the fertilisation potential of the Mt. Hudson ash deposited in Patagonia $\left(\sim 1.6 \mathrm{~km}^{3}\right)$, which was easily remobilised by the roaring forties during several months after the eruption has never been considered.

Another interesting event is the eruption of Huaynaputina in Peru in 1600 , which produced more than $9.6 \mathrm{~km}^{3}$ of volcanic ash [158], which is known to have settled into the tropical Pacific as well as the Southern Ocean, two large HNLC areas. An iron-fertilisation effect could partly explain the $10 \mathrm{ppm}$ decrease in atmospheric $\mathrm{CO}_{2}$ concentration measured in Antarctic ice cores after 1600 [159].

Ocean iron fertilisation may also affect the climate relevant exchange of trace gases between the ocean and the atmosphere. An increase of the MPP is accompanied by an increased contribution of organic carbon (OC) to submicron marine aerosols [160] and the release of dimethylsulfide (DMS) [161], oxidised to sulfate in the atmosphere. OC and sulfate aerosols can act as efficient cloud condensation nuclei and significantly influence cloud properties via the indirect aerosol effects (see Section 5.4.2; [120]), thereby further cooling the Earth's surface.

\section{Future Research Needs}

Although there are substantial differences in the history of mineral dust and volcanic ash particles before they are released into the atmosphere (see Sections 2 and 3), there are on the other hand a number of similarities in atmospheric processing at ambient temperatures (see Section 4.2) and environmental and climate impacts (see Section 5). Therefore, this review tries to trigger a closer cooperation between the research communities studying mineral dust and volcanic ash atmospheric chemical modifications and impacts.

Model parameterisations of volcanic ash remobilisation from its deposits on land build on mineral dust mobilisation schemes [10]. However, as the availability of ash in its deposits is limited, modified approaches will be necessary considering mass conserving parameterisations, where the migration of deposits is also included. Such parameterisations might be of interest for mineral dust researchers as well.

The extreme conditions for multiphase chemistry in volcanic plumes (see Section 4.1) regarding temperature and their associated gradients, acidity, lightning, and particle load represent an obstacle which hindered an overall understanding of the important processes up to now. Despite these difficulties, the multiphase volcanic plume chemistry under extreme conditions, however, offers the possibilities to illuminate processes which might also be important for mineral dust atmospheric chemical processing under less extreme conditions. Here, in particular, the formation of bioavailable iron on mineral dust and volcanic ash surfaces for ocean fertilisation (see Section 5.4.3) is emphasised. Joint experimental and modelling research projects between mineral dust [18] and volcanic ash researchers could substantially increase our incomplete understanding beyond what we know today, particularly from leaching experiments [74]. Although leaching experiments are extremely important for 
our current knowledge, they could be even more important if standard protocols would be defined and applied to allow a comparison between the experiments conducted at different laboratories [97]. Also particle size distributions and mineralogy for particle diameters substantially smaller than $2 \mu \mathrm{m}$ should be increasingly studied, particularly by volcanological researchers, as these particles are subject to long-range transport.

During a volcanic eruption, ash particles are easily injected into atmospheric regimes where freezing temperatures prevail, and therefore a better understanding of the processes affected by freezing temperatures, like IN formations or Fe mobilisation and their climate impacts [99], should be studied more systematically. CCN and IN formation is linked with wet deposition processes of mineral dust and volcanic ash out of the atmosphere. Regarding volcanic ash, an improved knowledge of aggregation (see Section 3.3), a deposition process reducing the amount of volcanic ash for long-range transport, is urgently needed. This process is insufficiently handled in all ash dispersion models [162]. Reference [62] requests continued interaction between the meteorological and volcanological communities to achieve advances in understanding the fundamentals of ash aggregation. Besides ash-ice aggregation processes, which considerably increase the terminal settling velocity of the aggregates in comparison to the single fine ash particle and thereby increase the removal rate of volcanic ash, the process of wet deposition of volcanic ash must also be considered as a nonlinear interaction process between volcanic ash and meteorological clouds. Even without the effects of volcanic ash, understanding of the fundamentals of cloud formation is challenging for atmospheric scientists. Interactions of aerosols, including mineral dust, with water and ice in atmospheric clouds and their influence on cloud formation, lifetime, and precipitation formation is one of the hot topics in climate research [120].

For paleoclimate research, the results from terrestrial and marine environmental archives, namely, ice, peat, sea, and ocean sediment cores for mineral dust [139] and volcanic ash deposition $[58,59]$, need to be assembled to better assess the climate impacts of volcanic ash versus mineral dust during the geological past. However, until we have a good understanding of present day processes, we will not be able to adequately address these processes either in the palaeorecords or with regard to the future impacts of mineral dust in contrast to volcanic ash on climate.

\section{Acknowledgments}

The financial support through the Cluster of Excellence "CliSAP" (EXC177), University of Hamburg, funded through the German Science Foundation (DFG) is gratefully acknowledged. The author thanks Michael Hemming, Gholamali Hoshyaripour, and Matthias Hort for their comments on the paper.

\section{References}

[1] R. Sparks, M. Bursik, J. Gilbert, L. Glaze, H. Sigurdsson, and A. Woods, Volcanic Plumes, John Wiley, Chichester, UK, 1997.
[2] W. I. Rose and A. J. Durant, "Fine ash content of explosive eruptions," Journal of Volcanology and Geothermal Research, vol. 186, no. 1-2, pp. 32-39, 2009.

[3] D. B. Dingwell, Y. Lavallée, and U. Kueppers, "Volcanic ash: a primary agent in the Earth system," Physics and Chemistry of the Earth, vol. 45-46, pp. 2-4, 2012.

[4] B. Zimanowski, K. Wohletz, P. Dellino, and R. Büttner, “The volcanic ash problem," Journal of Volcanology and Geothermal Research, vol. 122, no. 1-2, pp. 1-5, 2003.

[5] A. Robock, "Volcanic eruptions and climate," Reviews of Geophysics, vol. 38, no. 2, pp. 191-219, 2000.

[6] R. J. Brown, C. Bonadonna, and A. J. Durant, "A review of volcanic ash aggregation," Physics and Chemistry of the Earth, vol. 45-46, pp. 65-78, 2012.

[7] P. V. Hobbs, D. A. Hegg, and L. F. Radke, "Resuspension of volcanic ash from Mount St. Helens," Journal of Geophysical Research, vol. 88, no. 6, pp. 3919-3921, 1983.

[8] D. Hadley, G. L. Hufford, and J. J. Simpson, "Resuspension of relic volcanic ash and dust from katmai: still an aviation hazard," Weather and Forecasting, vol. 19, pp. 829-840, 2004.

[9] T. M. Wilson, J. W. Cole, C. Stewart, S. J. Cronin, and D. M. Johnston, "Ash storms: impacts of wind-remobilised volcanic ash on rural communities and agriculture following the 1991 Hudson eruption, southern Patagonia, Chile," Bulletin of Volcanology, vol. 73, no. 3, pp. 223-239, 2011.

[10] S. J. Leadbetter, M. C. Hort, S. Von Lwis, K. Weber, and C. S. Witham, "Modeling the resuspension of ash deposited during the eruption of Eyjafjallajökull in spring 2010," Journal of Geophysical Research, vol. 117, no. D20, 2012.

[11] T. Thorsteinsson, G. Gísladóttir, J. Bullard, and G. McTainsh, "Dust storm contributions to airborne particulate matter in Reykjavík, Iceland," Atmospheric Environment, vol. 45, no. 32, pp. 5924-5933, 2011.

[12] T. Thorsteinsson, T. Jóhannsson, A. Stohl, and N. I. Kristiansen, "High levels of particulate matter in Iceland due to direct ash emissions by the Eyjafjallajökull eruption and resuspension of deposited ash," Journal of Geophysical Research B, vol. 117, no. B9, 2012.

[13] I. Tegen and I. Fung, "Modeling of mineral dust in the atmosphere: sources, transport, and optical thickness," Journal of Geophysical Research, vol. 99, no. D11, pp. 22897-22914, 1994.

[14] J. M. Prospero, P. Ginoux, O. Torres, S. E. Nicholson, and T. E. Gill, "Environmental characterization of global sources of atmospheric soil dust identified with the Nimbus 7 Total Ozone Mapping Spectrometer (TOMS) absorbing aerosol product," Reviews of Geophysics, vol. 40, no. 1, pp. 2-1-2-31, 2002.

[15] T. D. Jickells, Z. S. An, K. K. Andersen et al., "Global iron connections between desert dust, ocean biogeochemistry, and climate," Science, vol. 308, no. 5718, pp. 67-71, 2005.

[16] N. M. Mahowald, A. R. Baker, G. Bergametti et al., "Atmospheric global dust cycle and iron inputs to the ocean," Global Biogeochemical Cycles, vol. 19, no. 4, 2005.

[17] Y. Shao, K.-H. Wyrwoll, A. Chappell et al., "Dust cycle: an emerging core theme in Earth system science," Aeolian Research, vol. 2, no. 4, pp. 181-204, 2011.

[18] M. Schulz, J. M. Prospero, A. R. Baker et al., "Atmospheric transport and deposition of mineral dust to the ocean: implications for research need," Environmental Science and Technology, vol. 46, pp. 10390-10404, 2012.

[19] N. Huneeus, M. Schulz, Y. Balkanski et al., "Global dust model intercomparison in AeroCom phase I," Atmospheric Chemistry and Physics, vol. 11, no. 15, pp. 7781-7816, 2011. 
[20] D. Rosenfeld, Y. Rudich, and R. Lahav, "Desert dust suppressing precipitation: a possible desertification feedback loop," Proceedings of the National Academy of Sciences of the United States of America, vol. 98, no. 11, pp. 5975-5980, 2001.

[21] P. Kumar, I. N. Sokolik, and A. Nenes, "Measurements of cloud condensation nuclei activity and droplet activation kinetics of fresh unprocessed regional dust samples and minerals," Atmospheric Chemistry and Physics, vol. 11, no. 7, pp. 3527-3541, 2011.

[22] F. J. Dentener, G. R. Carmichael, Y. Zhang, J. Lelieveld, and P. J. Crutzen, "Role of mineral aerosol as a reactive surface in the global troposphere," Journal of Geophysical Research, vol. 101, no. D17, pp. 22869-22889, 1996.

[23] S. E. Bauer, Y. Balkanski, M. Schulz, D. A. Hauglustine, and F. Dentener, "Global modeling of heterogenous chemistry on mineral aerosol surfaces: influence on tropospheric ozone chemistry and comparison to observations," Journal of Geophysical Research, vol. 109, no. 2, p. D2, 2004.

[24] J. H. Martin, "Glacial-interglacial $\mathrm{CO}_{2}$ change: the iron hypothesis," Paleoceanography, vol. 5, no. 1, pp. 1-13, 1990.

[25] I. Koren, Y. J. Kaufman, R. Washington et al., "The Bodélé depression: a single spot in the Sahara that provides most of the mineral dust to the Amazon forest," Environmental Research Letters, vol. 1, no. 1, Article ID 014005, 2006.

[26] J. G. Calvert, Glossary of Atmospheric Chemistry Terms, IUPAC, 1990.

[27] G. Heiken, "Morphology and Petrography of volcanic ashes," Geological Society of America Bulletin, vol. 83, pp. 1961-1988, 1972.

[28] H. U. Schmincke, Volcanism, Springer, Berlin, Germany, 2004.

[29] M. Nakagawa and T. Ohba, "Minerals in volcanic ash 1: primary minerals and volcanic glass," Global Environmental Research, vol. 6, pp. 41-51, 2003.

[30] Z. Shi, M. D. Krom, T. D. Jickels et al., "Impacts on iron solubility in the mineral dust by processes in the source region and the atmosphere: a review," Aeolian Research, vol. 5, pp. 21-42, 2012.

[31] P. Formenti, L. Schuetz, Y. Balkanski et al., "Recent progress in understanding physical and chemical properties of African and Asian mineral dust," Atmospheric Chemistry and Physics, vol. 11, pp. 8231-8256, 2011.

[32] B. Langmann, A. Folch, M. Hensch, and V. Matthias, "Volcanic ash over Europe during the eruption of Eyjafjallajökull on Iceland, April-May 2010," Atmospheric Environment, vol. 48, pp. $1-8,2012$.

[33] S. A. Colgate and T. Sigurgeirsson, "Dynamic mixing of water and lava," Nature, vol. 244, no. 5418, pp. 552-555, 1973.

[34] S. Dartevelle, G. G. J. Ernst, and A. Bernard, "Origin of the Mount Pinatubo climactic eruption cloud: implications for volcanic hazards and atmospheric impacts," Geology, vol. 30, no. 7, pp. 663-666, 2002.

[35] Y. H. Lee, K. Chen, and P. J. Adams, "Development of a global model of mineral dust aerosol microphysics," Atmospheric Chemistry and Physics, vol. 9, no. 7, pp. 2441-2458, 2009.

[36] T. M. Wilson, C. Stewart, V. Sword-Daniels et al., "Volcanic ash impacts on critical infrastructure," Physics and Chemistry of the Earth, vol. 45-46, no. 5, 23 pages, 2012.

[37] P. M. Ayris and P. Delmelle, "The immediate environmental effects of tephra emission," Bulletin of Volcanology, vol. 74, pp. 1905-1936, 2012.

[38] R. B. Symonds, W. I. Rose, G. J. S. Bluth, and T. M. Gerlach, "Volcanic gas studies: methods, results and applications," in
Volatiles in Magma, M. R. Caroll and J. R. Holloway, Eds., vol. 30, pp. 1-66, Reviews in Mineralogy and Geochemistry, 1994.

[39] P. Delmelle, F. Villiéras, and M. Pelletier, "Surface area, porosity and water adsorption properties of fine volcanic ash particles," Bulletin of Volcanology, vol. 67, no. 2, pp. 160-169, 2005.

[40] S. Joussaume, "3-dimensional simulations of the atmospheric cycle of desert dust particles using a general-circulation model," Journal of Geophysical Research, vol. 95, pp. 1909-1941, 1990.

[41] N. Mahowald, K. Kohfeld, M. Hansson et al., "Dust sources and deposition during the last glacial maximum and current climate: a comparison of model results with paleodata from ice cores and marine sediments," Journal of Geophysical Research, vol. 104, no. D13, pp. 15895-15916, 1999.

[42] B. Marticorena and G. Bergametti, "Modeling the atmospheric dust cycle: 1 . Design of a soil-derived dust emission scheme," Journal of Geophysical Research, vol. 100, no. 8, pp. 16415-16430, 1995.

[43] I. Tegen, M. Werner, S. P. Harrison, and K. E. Kohfeld, "Relative importance of climate and land use in determining present and future global soil dust emission," Geophysical Research Letters, vol. 31, no. 5, 2004.

[44] C. S. Zender, H. Bian, and D. Newman, "Mineral Dust Entrainment and Deposition (DEAD) model: description and 1990s dust climatology," Journal of Geophysical Research, vol. 108, no. D14, 2003.

[45] P. Formenti, J. L. Rajot, K. Desboeufs et al., "Airborne observations of mineral dust over western Africa in the summer Monsoon season: spatial and vertical variability of physicochemical and optical properties," Atmospheric Chemistry and Physics, vol. 11, no. 13, pp. 6387-6410, 2011.

[46] C. G. Newhall and S. Self, "The volcanic explosivity index ( VEI): an estimate of explosive magnitude for historical volcanism," Journal of Geophysical Research, vol. 87, no. C2, pp. 1231-1238, 1982.

[47] T. Simkin and I. Siebert, Volcanoes of the World, Smithonian Institution; Geoscience Press, Misoula, Mont, USA, 1994.

[48] T. A. Mather, D. M. Pyle, and C. Oppenheimer, "Tropospheric volcanic aerosol," in Volcanism and the Earth's Atmosphere, Geophysical Monograph, vol. 139, pp. 89-211, 2003.

[49] B. Langmann, K. Zaksek, and M. Hort, "Atmospheric distribution and removal of volcanic ash after the eruption of Kasatochi volcano: a regional model study," Journal of Geophysical Research, vol. 115, no. D2, 2010.

[50] B. Marticorena, B. Chatenet, J. L. Rajot et al., "Temporal variability of mineral dust concentrations over West Africa: analyses of a pluriannual monitoring from the AMMA Sahelian Dust Transect," Atmospheric Chemistry and Physics, vol. 10, no. 18, pp. 8899-8915, 2010.

[51] M. Mikami, O. Abe, M. Du et al., "The impact of Aeolian dust on climate: sino-Japanese cooperative project ADEC," Journal of Arid Land Studies, vol. 11, pp. 211-222, 2002.

[52] C. Hoffmann, R. Funk, M. Sommer, and Y. Li, “Temporal variations in PM10 and particle size distribution during Asian dust storms in Inner Mongolia," Atmospheric Environment, vol. 42, no. 36, pp. 8422-8431, 2008.

[53] I. Chiapello, "Origins of African dust transported over the northeastern tropical Atlantic," Journal of Geophysical Research, vol. 102, no. D12, pp. 13701-13709, 1997.

[54] A. J. Prata and A. T. Prata, "Eyjafjallajökull volcanic ash concentrations determined using Spin enhanced visible and infrared imager measurements," Journal of Geophysical Research, vol. 117, no. D20, 2012. 
[55] H. N. Webster, D. J. Thomson, B. T. Johnson et al., "Operational prediction of ash concentrations in the distal volcanic cloud from the 2010 Eyjafjallajökull eruption," Journal of Geophysical Research D, vol. 117, no. D20, 2012.

[56] J. H. Seinfeld and S. N. Pandis, Atmospheric Chemistry and Physics: From Air Pollution to Climate Change, John Wiley, New York, NY, USA, 2006.

[57] N. Olgun, S. Duggen, P. L. Croot et al., "Surface ocean iron fertilization: the role of airborne volcanic ash from subduction zone and hot spot volcanoes and related iron fluxes into the Pacific Ocean," Global Biogeochemical Cycles, vol. 25, no. 4, 2011.

[58] S. M. Straub and H. U. Schmincke, "Evaluating the tephra input into Pacific Ocean sediments: distribution in space and time," Geologische Rundschau, vol. 87, no. 3, pp. 461-476, 1998.

[59] S. Kutterolf, A. Freundt, U. Schacht et al., "Pacific offshore record of plinian arc volcanism in Central America: 3. Application to forearc geology," Geochemistry, Geophysics, Geosystems, vol. 9, no. 2, 2008.

[60] B. Langmann, K. Zakšek, M. Hort, and S. Duggen, "Volcanic ash as fertiliser for the surface ocean," Atmospheric Chemistry and Physics, vol. 10, no. 8, pp. 3891-3899, 2010.

[61] D. M. Gaiero, J.-L. Probst, P. J. Depetris, S. M. Bidart, and L. Leleyter, "Iron and other transition metals in Patagonian riverborne and windborne materials: geochemical control and transport to the southern South Atlantic Ocean," Geochimica et Cosmochimica Acta, vol. 67, no. 19, pp. 3603-3623, 2003.

[62] W. I. Rose and A. J. Durant, "Fate of volcanic ash: aggregation and fallout," Geology, vol. 39, no. 9, pp. 895-896, 2011.

[63] A. J. Durant, W. I. Rose, A. M. Sarna-Wojcicki, S. Carey, and A. C. M. Volentik, "Hydrometeor-enhanced tephra sedimentation: constraints from the 18 May 1980 eruption of Mount St. Helens," Journal of Geophysical Research, vol. 114, no. B3, 2009.

[64] C. Bonadonna, R. Genco, M. Gouhier et al., “Tephra sedimentation during the 2010 Eyjafjallajökull eruption (Iceland) from deposit, radar, and satellite observations," Journal of Geophysical Research, vol. 116, no. B12, 2011.

[65] A. Folch, "A review of tephra transport and dispersal models: evolution, current status and future perspectives," Journal of Volcanology and Geothermal Research, vol. 235, pp. 96-115, 2012.

[66] C. Textor, H. F. Graf, C. Timmreck, and A. Robock, "Emissions from volcanoes," in Emissions of Chemical Compounds and Aerosols in the Atmosphere, C. Granier, C. Reeves, and P. Artaxo, Eds., vol. 18 of Advances in Global Change Research, pp. 269-303, Kluwer, Dordrecht, The Netherlands, 2004.

[67] L. G. Mastin, "A user-friendly one-dimensional model for wet volcanic plumes," Geochemistry, Geophysics, Geosystems, vol. 8, no. 3, 2007.

[68] M. R. James, L. Wilson, S. J. Lane et al., "Electrical charging of volcanic plumes," Space Science Reviews, vol. 137, no. 1-4, pp. 399-418, 2008.

[69] S. R. McNutt and E. R. Williams, "Volcanic lightning: global observations and constraints on source mechanisms," Bulletin of Volcanology, vol. 72, no. 10, pp. 1153-1167, 2010.

[70] W. I. Rose, "Scavenging of volcanic aerosol by ash: atmospheric and volcanologic implications," Geology, vol. 5, pp. 621-624, 1977.

[71] N. Oskarsson, "The interaction between volcanic gases and tephra: fluorine adhering to tephra of the 1970 Hekla eruption," Journal of Volcanology \& Geothermal Research, vol. 8, no. 2-4, pp. 251-266, 1980.
[72] E. Bagnato, A. Aiuppa, A. Bertagnini et al., "Scavenging of sulphur, halogens and trace metals by volcanic ash: the 2010 Eyjafjallajökull eruption," Geochimica Et Cosmochimica Acta, vol. 103, pp. 138-160, 2013.

[73] J. M. de Moor, T. P. Fischer, D. R. Hilton, E. Hauri, L. A. Jaffe, and J. T. Camacho, "Degassing at Anatahan volcano during the May 2003 eruption: implications from petrology, ash leachates, and $\mathrm{SO}_{2}$ emissions," Journal of Volcanology and Geothermal Research, vol. 146, no. 1-3, pp. 117-138, 2005.

[74] C. S. Witham, C. Oppenheimer, and C. J. Horwell, "Volcanic ash-leachates: a review and recommendations for sampling methods," Journal of Volcanology and Geothermal Research, vol. 141, no. 3-4, pp. 299-326, 2005.

[75] P. Frogner, S. R. Gíslason, and N. Óskarsson, "Fertilizing potential of volcanic ash in ocean surface water," Geology, vol. 29, no. 6, pp. 487-490, 2001.

[76] S. Duggen, P. Croot, U. Schacht, and L. Hoffmann, "Subduction zone volcanic ash can fertilize the surface ocean and stimulate phytoplankton growth: evidence from biogeochemical experiments and satellite data," Geophysical Research Letters, vol. 34, no. 1, Article ID L01612, 2007.

[77] S. Duggen, N. Olgun, P. Croot et al., "The role of airborne volcanic ash for the surface ocean biogeochemical iron-cycle: a review," Biogeosciences, vol. 7, no. 3, pp. 827-844, 2010.

[78] P. S. Taylor and R. E. Stoiber, "Soluble material on ash from active Central American volcanoes," Geological Society of America Bulletin, vol. 84, pp. 1031-1042, 1973.

[79] D. B. Smith, R. A. Zielinski, W. I. Rose Jr., and B. J. Huebert, "Water-soluble material on aerosols collected within volcanic eruption clouds (Fuego, Pacaya, Santiaguito, Guatamala)," Journal of Geophysical Research, vol. 87, no. 7, pp. 4963-4972, 1982.

[80] P. Delmelle, M. Lambert, Y. Dufrêne, P. Gerin, and N. Óskarsson, "Gas/aerosol-ash interaction in volcanic plumes: new insights from surface analyses of fine ash particles," Earth and Planetary Science Letters, vol. 259, no. 1-2, pp. 159-170, 2007.

[81] P. M. Ayris, A. F. Lee, K. Wilson, U. Kueppers, D. B. Dingwell, and P. Delmelle, " $\mathrm{SO}_{2}$ sequestration in large volcanic eruptions: high-temperature scavenging by tephra," Geochimica Et Cosmochimica Acta, vol. 110, pp. 58-69, 2013.

[82] C. Textor, H. F. Graf, M. Herzog, J. M. Oberhuber, W. I. Rose, and G. G. J. Ernst, "Volcanic particle aggregation in explosive eruption columns. Part I: parameterization of the microphysics of hydrometeors and ash," Journal of Volcanology and Geothermal Research, vol. 150, no. 4, pp. 359-377, 2006.

[83] P. Ayris and P. Delmelle, "Volcanic and atmospheric controls on ash iron solubility: a review," Physics and Chemistry of the Earth, vol. 45-46, pp. 103-112, 2012.

[84] M. M. Halmer, H.-U. Schmincke, and H.-F. Graf, "The annual volcanic gas input into the atmosphere, in particular into the stratosphere: a global data set for the past 100 years," Journal of Volcanology and Geothermal Research, vol. 115, no. 3-4, pp. 511$528,2002$.

[85] C. Gao, A. Robock, and C. Ammann, "Volcanic forcing of climate over the past 1500 years: an improved ice core-based index for climate models," Journal of Geophysical Research, vol. 113, no. D23, 2008.

[86] N. Meskhidze, W. L. Chameides, A. Nenes, and G. Chen, "Iron mobilization in mineral dust: can anthropogenic $\mathrm{SO}_{2}$ emissions affect ocean productivity?" Geophysical Research Letters, vol. 30, no. 21, 2003.

[87] J. Fero, S. N. Carey, and J. T. Merrill, "Simulating the dispersal of tephra from the 1991 Pinatubo eruption: implications for the 
formation of widespread ash layers," Journal of Volcanology and Geothermal Research, vol. 186, no. 1-2, pp. 120-131, 2009.

[88] M. Ullerstam, R. Vogt, S. Langer, and E. Ljungström, "The kinetics and mechanism of $\mathrm{SO}_{2}$ oxidation by $\mathrm{O}_{3}$ on mineral dust," Physical Chemistry Chemical Physics, vol. 4, no. 19, pp. 4694-4699, 2002.

[89] M. Ndour, P. Conchon, B. D’Anna, O. Ka, and C. George, "Photochemistry of mineral dust surface as a potential atmospheric renoxification process," Geophysical Research Letters, vol. 36, no. 5, 2009.

[90] R. C. Sullivan, S. A. Guazzotti, D. A. Sodeman, and K. A. Prather, "Direct observations of the atmospheric processing of Asian mineral dust," Atmospheric Chemistry and Physics, vol. 7, no. 5, pp. 1213-1236, 2007.

[91] Y. Dupart, S. M. King, B. Nekat et al., "Mineral dust photochemistry induces nucleation events in the presence of $\mathrm{SO}_{2}$," Proceedings of the National Academy of Science of the United States of America, vol. 109, pp. 20842-20847, 2012.

[92] S. Wurzler, T. G. Reisin, and Z. Levin, "Modification of mineral dust particles by cloud processing and subsequent effects on drop size distributions," Journal of Geophysical Research D, vol. 105, no. D4, pp. 4501-4512, 2000.

[93] D. S. Mackie, P. W. Boyd, K. A. Hunter, and G. H. McTainsh, "Simulating the cloud processing of iron in Australian dust: $\mathrm{pH}$ and dust concentration," Geophysical Research Letters, vol. 32, no. 6, 2005.

[94] A. Matsuki, A. Schwarzenboeck, H. Venzac, P. Laj, S. Crumeyrolle, and L. Gomes, "Cloud processing of mineral dust: direct comparison of cloud residual and clear sky particles during AMMA aircraft campaign in summer 2006," Atmospheric Chemistry and Physics, vol. 10, no. 3, pp. 1057-1069, 2010.

[95] H. Bingemer, H. Klein, M. Ebert et al., "Atmospheric ice nuclei in the Eyjafjallajökull volcanic ash plume," Atmospheric Chemistry and Physics, vol. 12, pp. 857-867, 2012.

[96] F. Solmon, P. Y. Chuang, N. Meskhidze, and Y. Chen, "Acidic processing of mineral dust iron by anthropogenic compounds over the north Pacific Ocean," Journal of Geophysical Research, vol. 114, no. D2, 2009.

[97] A. R. Baker and P. L. Croot, "Atmospheric and marine controls on aerosol iron solubility in seawater," Marine Chemistry, vol. 120, no. 1-4, pp. 4-13, 2010.

[98] N. Meskhidze, W. L. Chameides, and A. Nenes, "Dust and pollution: a recipe for enhanced ocean fertilization?" Journal of Geophysical Research D, vol. 110, no. D3, 2005.

[99] D. Jeong, K. Kim, and W. Choi, "Accelerated dissolution of iron oxides in ice," Atmospheric Chemistry and Physics, vol. 12, pp. 11125-11133, 2012.

[100] A. J. Durant, R. A. Shaw, W. I. Rose, Y. Mi, and G. G. J. Ernst, "Ice nucleation and overseeding of ice in volcanic clouds," Journal of Geophysical Research, vol. 113, no. D9, 2008.

[101] Z. Shi, D. Zhang, M. Hayashi, H. Ogata, H. Ji, and W. Fujiie, "Influences of sulfate and nitrate on the hygroscopic behaviour of coarse dust particles," Atmospheric Environment, vol. 42, no. 4, pp. 822-827, 2008.

[102] T. L. Lathem, P. Kumar, A. Nenes et al., "Hygroscopic properties of volcanic ash," Geophysical Research Letters, vol. 38, no. 11, Article ID L11802, 2011.

[103] R. A. Dahlgren, F. C. Uoolim, and W. H. Casey, "Field weathering rates of Mt. St. Helens tephra," Geochimica et Cosmochimica Acta, vol. 63, no. 5, pp. 587-598, 1999.
[104] A. F. White and S. L. Brantley, "Chemical weathering rates of silicate minerals: an overview," Reviews in Mineralogy and Geochemistry, vol. 31, pp. 1-22, 1995.

[105] J.-I. Jeong and S.-U. Park, "Interaction of gaseous pollutants with aerosols in Asia during March 2002," Science of the Total Environment, vol. 392, no. 2-3, pp. 262-276, 2008.

[106] H. Yuan, G. Zhuang, J. Li, Z. Wang, and J. Li, "Mixing of mineral with pollution aerosols in dust season in Beijing: revealed by source apportionment study," Atmospheric Environment, vol. 42, no. 9, pp. 2141-2157, 2008.

[107] IPCC (International Panel of Climate Change), Fourth Assessment Report: Climate Change, 2007.

[108] C. J. Horwell and P. J. Baxter, "The respiratory health hazards of volcanic ash: a review for volcanic risk mitigation," Bulletin of Volcanology, vol. 69, no. 1, pp. 1-24, 2006.

[109] M. G. Dunn, A. J. Baran, and J. Miatech, "Operation of gas turbine engines in volcanic ash clouds," Journal of Engineering for Gas Turbines and Power, vol. 118, no. 4, pp. 724-731, 1996.

[110] M. Guffanti, T. J. Casadevall, and K. Budding, "1953-2009: Encounters of Aircraft with Volcanic Ash Clouds, A Compilation of Known Incidents," U.S. Geological Survey Data Series 545, 12 p., Plus 4 Appendixes Including the Compilation Database, 2010, http://pubs.usgs.gov/ds/545/ .

[111] B. Weinzierl, D. Sauer, A. Minikin et al., "On the visibility of airborne volcanic ash and mineral dust from the pilot's perspective in flight," Physics and Chemistry of the Earth, vol. 45-46, pp. 87-102, 2012.

[112] R. J. Cook, J. C. Barron, R. I. Papendick, and G. J. Williams III, "Impact on agriculture of the Mount St. Helens eruptions," Science, vol. 211, no. 4477, pp. 16-22, 1981.

[113] C. Mass and A. Robock, "The short-term influence of the Mount St. Helens volcanic eruption on surface temperature in the northwest United States ( Idaho, Montana)," Monthly Weather Review, vol. 110, no. 6, pp. 614-622, 1982.

[114] M. T. Jones, R. S. J. Sparks, and P. J. Valdes, “The climatic impact of supervolcanic ash blankets," Climate Dynamics, vol. 29, no. 6, pp. 553-564, 2007.

[115] Y. J. Kaufman, D. Tanré, O. Dubovik, A. Karnieli, and L. A. Remer, "Absorption of sunlight by dust as inferred from satellite and ground-based remote sensing," Geophysical Research Letters, vol. 28, no. 8, pp. 1479-1482, 2001.

[116] H. E. Redmond, K. D. Dial, and J. E. Thompson, "Light scattering and absorption by wind blown dust: theory, measurement, and recent data," Aeolian Research, vol. 2, no. 1, pp. 5-26, 2010.

[117] J. S. Reid, H. H. Jonsson, H. B. Maring et al., "Comparison of size and morphological measurements of coarse mode dust particles from Africa," Journal of Geophysical Research, vol. 108, no. D19, 2003.

[118] S. Groß, V. Freudenthaler, M. Wiegner, J. Gasteiger, A. Geiß, and F. Schnell, "Dual-wavelength linear depolarization ratio of volcanic aerosols: lidar measurements of the Eyjafjallajökull plume over Maisach, Germany," Atmospheric Environment, vol. 48, pp. 85-96, 2012.

[119] S. E. Bauer, M. I. Mishchenko, A. A. Lacis, S. Zhang, J. Perlwitz, and S. M. Metzger, "Do sulfate and nitrate coatings on mineral dust have important effects on radiative properties and climate modeling?" Journal of Geophysical Research, vol. 112, no. D6, 2007.

[120] U. Lohmann and J. Feichter, "Global indirect aerosol effects: a review," Atmospheric Chemistry and Physics, vol. 5, no. 3, pp. 715-737, 2005. 
[121] S. Twomey, "The influence of pollution on the shortwave albedo of clouds," Journal of Atmospheric Sciences, vol. 34, pp. 1149-1152, 1977.

[122] B. A. Albrecht, "Aerosols, cloud microphysics, and fractional cloudiness," Science, vol. 245, no. 4923, pp. 1227-1230, 1989.

[123] S. Gasso, "Satellite observations of the impact of weak volcanic activity on marine clouds," Journal of Geophysical Research, vol. 113, no. D14, 2008.

[124] F. J. Nober, H.-F. Graf, and D. Rosenfeld, "Sensitivity of the global circulation to the suppression of precipitation by anthropogenic aerosols," Global and Planetary Change, vol. 37, no. 1-2, pp. 57-80, 2003.

[125] H. R. Pruppacher and J. D. Klett, Microphysics of Clouds and Precipitation, Kluwer, Dordrecht, The Netherlands, 2nd edition, 1997.

[126] W. Szyrmer and I. Zawadzki, "Biogenic and anthropogenic sources of ice-forming nuclei: a review," Bulletin of the American Meteorological Society, vol. 78, no. 2, pp. 209-228, 1997.

[127] K. Diehl, C. Quick, S. Matthias-Maser, S. K. Mitra, and R. Jaenicke, "The ice nucleating ability of pollen Part I: laboratory studies in deposition and condensation freezing modes," Atmospheric Research, vol. 58, no. 2, pp. 75-87, 2001.

[128] K. Diehl, S. Matthias-Maser, R. Jaenicke, and S. K. Mitra, "The ice nucleating ability of pollen: Part II. Laboratory studies in immersion and contact freezing modes," Atmospheric Research, vol. 61, no. 2, pp. 125-133, 2002.

[129] P. J. DeMott, K. Sassen, M. R. Poellot et al., "African dust aerosols as atmospheric ice nuclei," Geophysical Research Letters, vol. 30, no. 14, 2003.

[130] P. Seifert, A. Ansmann, S. Groß et al., "Ice formation in ashinfluenced clouds after the eruption of the Eyjafjallajökull volcano in April 2010," Journal of Geophysical Research, vol. 116, no. D20, 2011.

[131] Y.-S. Choi, R. S. Lindzen, C.-H. Ho, and J. Kim, "Space observations of cold-cloud phase change," Proceedings of the National Academy of Sciences of the United States of America, vol. 107, no. 25, pp. 11211-11216, 2010.

[132] P. W. Boyd and M. J. Ellwood, "The biogeochemical cycle of iron in the ocean," Nature Geoscience, vol. 3, no. 10, pp. 675-682, 2010.

[133] L. Bopp, K. E. Kohfeld, C. Le Quéré, and O. Aumont, "Dust impact on marine biota and atmospheric $\mathrm{CO}_{2}$ during glacial periods," Paleoceanography, vol. 18, no. 2, 2003.

[134] R. Röthlisberger, M. Bigler, E. W. Wolff, F. Joos, E. Monnin, and M. A. Hutterli, "Ice core evidence for the extent of past atmospheric $\mathrm{CO}_{2}$ change due to iron fertilisation," Geophysical Research Letters, vol. 31, no. 16, 2004.

[135] F. Lambert, B. Delmonte, J. R. Petit et al., "Dust-climate couplings over the past 800,000 years from the EPICA Dome C ice core," Nature, vol. 452, no. 7187, pp. 616-619, 2008.

[136] J. K. B. Bishop, R. E. Davis, and J. T. Sherman, "Robotic observations of dust storm enhancement of carbon biomass in the North Pacific," Science, vol. 298, no. 5594, pp. 817-821, 2002.

[137] P. W. Boyd, C. S. Wong, J. Merrill et al., "Atmospheric iron supply and enhanced vertical carbon flux in the NE subarctic Pacific: is there a connection?" Global Biogeochemical Cycles, vol. 12, no. 3, pp. 429-441, 1998.

[138] A. Martínez-Garcia, A. Rosell-Melé, W. Geibert et al., "Links between iron supply, marine productivity, sea surface temperature, and $\mathrm{CO}_{2}$ over the last 1.1 Ma," Paleoceanography, vol. 24, no. $1,2009$.
[139] B. A. Maher, J. M. Prospero, D. Mackie, D. Gaiero, P. P. Hesse, and Y. Balkanski, "Global connections between aeolian dust, climate and ocean biogeochemistry at the present day and at the last glacial maximum," Earth-Science Reviews, vol. 99, no. 1-2, pp. 61-97, 2010.

[140] L. J. Hoffmann, E. Breitbarth, M. V. Ardelan et al., "Influence of trace metal release from volcanic ash on growth of Thalassiosira pseudonana and Emiliania huxleyi," Marine Chemistry, vol. 132133, pp. 28-33, 2012.

[141] E. P. Achterberg, C. M. Moore, A. Henson et al., "Natural iron fertilization by the Eyjafjallajökull volcanic eruption," Geophysical Research Letters, vol. 40, no. 5, pp. 921-926, 2013.

[142] M. T. Jones and S. R. Gislason, "Rapid releases of metal salts and nutrients following the deposition of volcanic ash into aqueous environments," Geochimica et Cosmochimica Acta, vol. 72, no. 15, pp. 3661-3680, 2008.

[143] R. C. Hamme, P. W. Webley, W. R. Crawford et al., "Volcanic ash fuels anomalous plankton bloom in subarctic northeast Pacific," Geophysical Research Letters, vol. 37, no. 19, Article ID L19604, 2010.

[144] D. Lockwood, P. D. Quay, M. T. Kavanaugh, L. W. Juranek, and R. A. Feely, "High-resolution estimates of net community production and air-sea $\mathrm{CO}_{2}$ flux in the northeast Pacific," Global Biogeochemical Cycles, vol. 26, no. 4, 2012.

[145] A. Lindenthal, B. Langmann, J. Paetsch, I. Lorkorwski, and M. Hort, "The ocean response to volcanic iron fertilization after the eruption of Kasatochi volcano: a regional biogeochemical model study," Biogeosciences, vol. 10, pp. 3715-3729, 2013.

[146] T. R. Parsons and F. A. Whitney, "Did volcanic ash from Mt. Kasatochi in 2008 contribute to a phenomenal increase in Fraser River sockeye salmon (Oncohynchus nerka) in 2010?” Fishery Oceanography, vol. 21, pp. 374-377, 2012.

[147] S. McKinnell, "Challenges for the Kasatochi volcano hypothesis as the cause of a large return of sockeye salmon (Oncorhynchus nerka) to the Fraser River in 2010," Fisheries Oceanography, 2013.

[148] B. R. Jicha, D. W. Scholl, and D. K. Rea, "Circum-Pacific arc flare-ups and global cooling near the Eocene-Oligocene boundary," Geology, vol. 37, no. 4, article 303, 2009.

[149] S. M. Cather, N. W. Dunbar, F. W. McDowell, W. C. McIntosh, and P. A. Scholle, "Climate forcing by iron fertilization from repeated ignimbrite eruptions: the icehouse-silicic large igneous province (SLIP) hypothesis," Geosphere, vol. 5, no. 3, pp. 315-324, 2009.

[150] R. C. Bay, N. Bramall, and P. B. Price, "Bipolar correlation of volcanism with millennial climate change," Proceedings of the National Academy of Sciences of the United States of America, vol. 101, no. 17, pp. 6341-6345, 2004.

[151] R. C. Bay, N. E. Bramall, P. B. Price et al., "Globally synchronous ice core volcanic tracers and abrupt cooling during the last glacial period," Journal of Geophysical Research, vol. 111, no. D11, 2006.

[152] S. Bains, R. D. Norris, R. M. Corfield, and K. L. Faul, “Termination of global warmth at the Palaeocene/Eocene boundary through productivity feedback," Nature, vol. 407, no. 6801, pp. 171-174, 2000.

[153] P. Censi, L. A. Randazzo, P. Zuddas, F. Saiano, P. Aricò, and S. Andò, "Trace element behaviour in seawater during Etna's pyroclastic activity in 2001: concurrent effects of nutrients and formation of alteration minerals," Journal of Volcanology and Geothermal Research, vol. 193, no. 1-2, pp. 106-116, 2010.

[154] J. L. Sarmiento, "Atmospheric $\mathrm{CO}_{2}$ stalled," Nature, vol. 365, no. 6448, pp. 697-698, 1993. 
[155] A. J. Watson, "Volcanic iron, $\mathrm{CO}_{2}$, ocean productivity and climate," Nature, vol. 385, no. 6617, pp. 587-588, 1997.

[156] L. M. Mercado, N. Bellouin, S. Sitch et al., "Impact of changes in diffuse radiation on the global land carbon sink," Nature, vol. 458, no. 7241, pp. 1014-1017, 2009.

[157] R. A. Scasso, H. Corbella, and P. Tiberi, "Sedimentological analysis of the tephra from the 12-15 August 1991 eruption of Hudson volcano," Bulletin of Volcanology, vol. 56, no. 2, pp. 121132, 1994.

[158] S. L. De Silva and G. A. Zielinski, "Global influence of the AD 1600 eruption of Huaynaputina, Peru," Nature, vol. 393, no. 6684, pp. 455-458, 1998.

[159] C. MacFarling Meure, D. Etheridge, C. Trudinger et al., "Law dome $\mathrm{CO}_{2}, \mathrm{CH}_{4}$ and $\mathrm{NCO}_{2} \mathrm{O}$ ice core records extended to 2000 years BP," Geophysical Research Letters, vol. 33, no. 14, 2006.

[160] C. D. O’Dowd, M. C. Facchini, F. Cavalli et al., "Biogenically driven organic contribution to marine aerosol," Nature, vol. 431, no. 7009, pp. 676-680, 2004.

[161] P. Liss, A. Chuck, D. Bakker, and S. Turner, "Ocean fertilization with iron: effects on climate and air quality," Tellus B, vol. 57, no. 3, pp. 269-271, 2005.

[162] C. Bonadonna and A. Foch, "Ash Dispersal Forecast and Civil Aviation Workshop-Consensual Document," 2011, https:// vhub.org/resources/503 . 

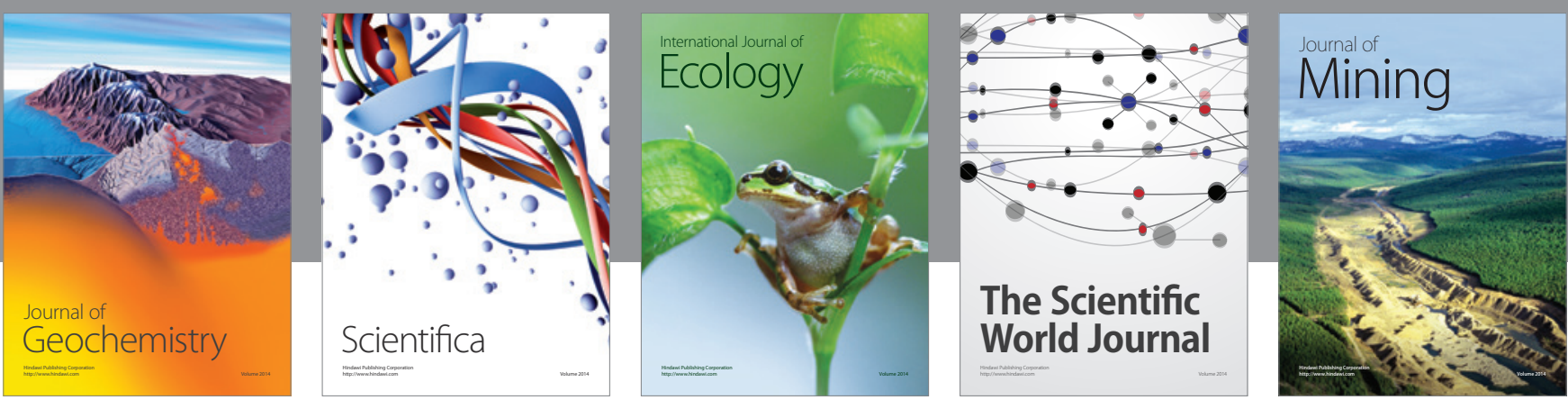

The Scientific World Journal
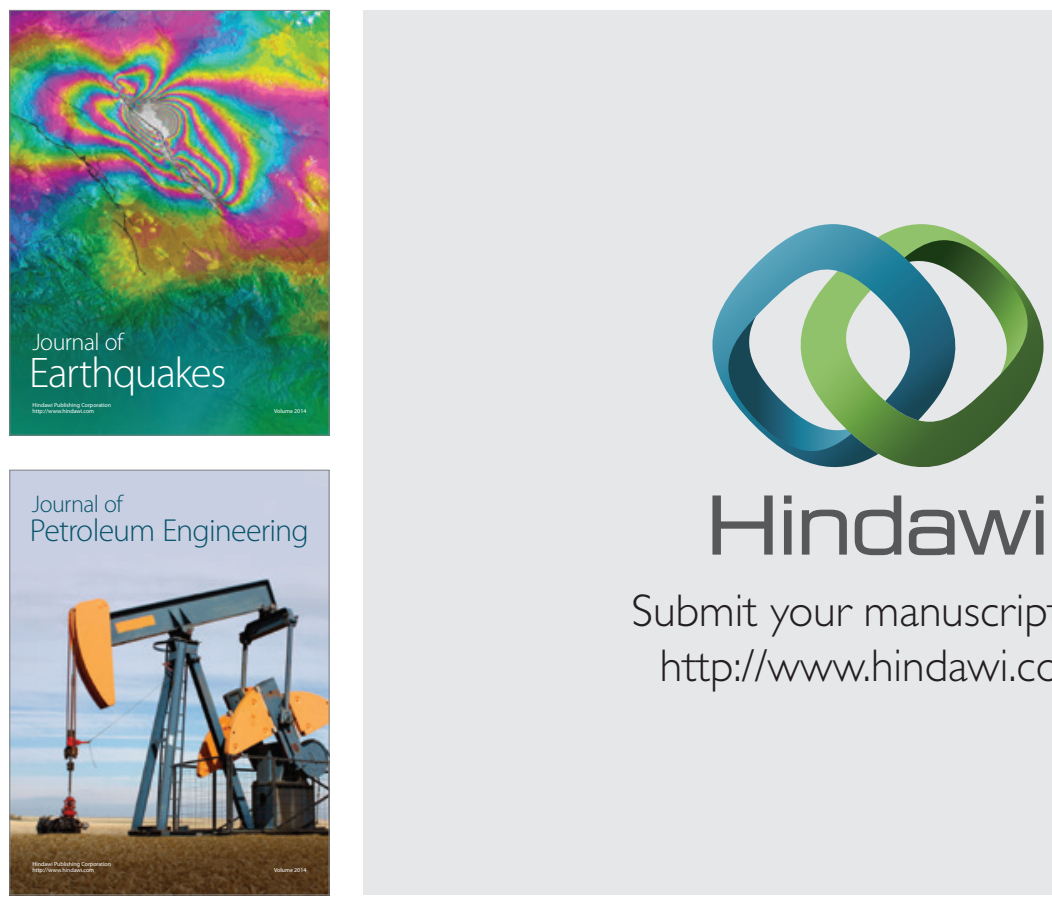

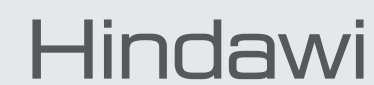

Submit your manuscripts at

http://www.hindawi.com
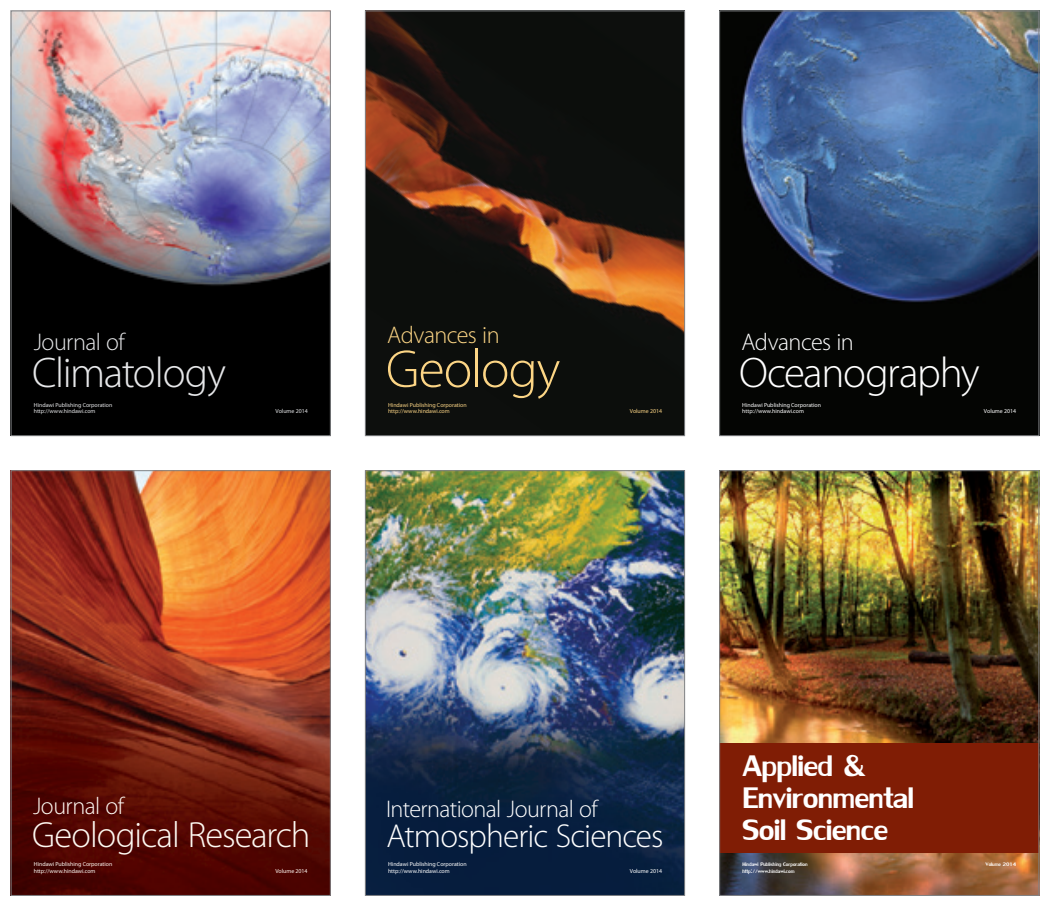
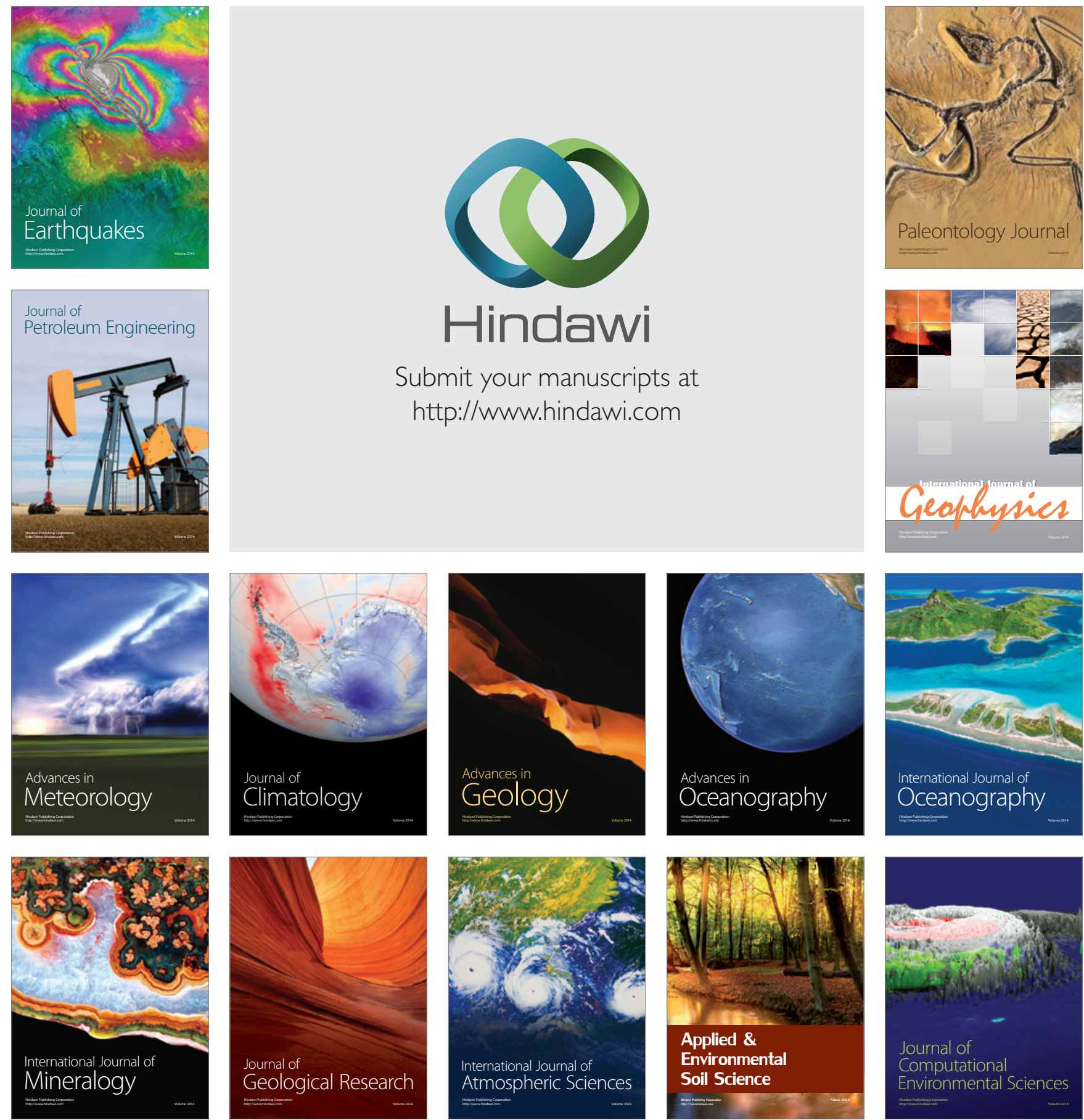